Historic, archived document

Do not assume content reflects current scientific knowledge, policies, or practices. 


\section{A MESSAGE ON} PASTURES AND

COVER CROPS

$$
\begin{aligned}
& \text { I, } I \text { स्द } 72 x
\end{aligned}
$$

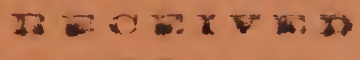

NELEMAR291930 के

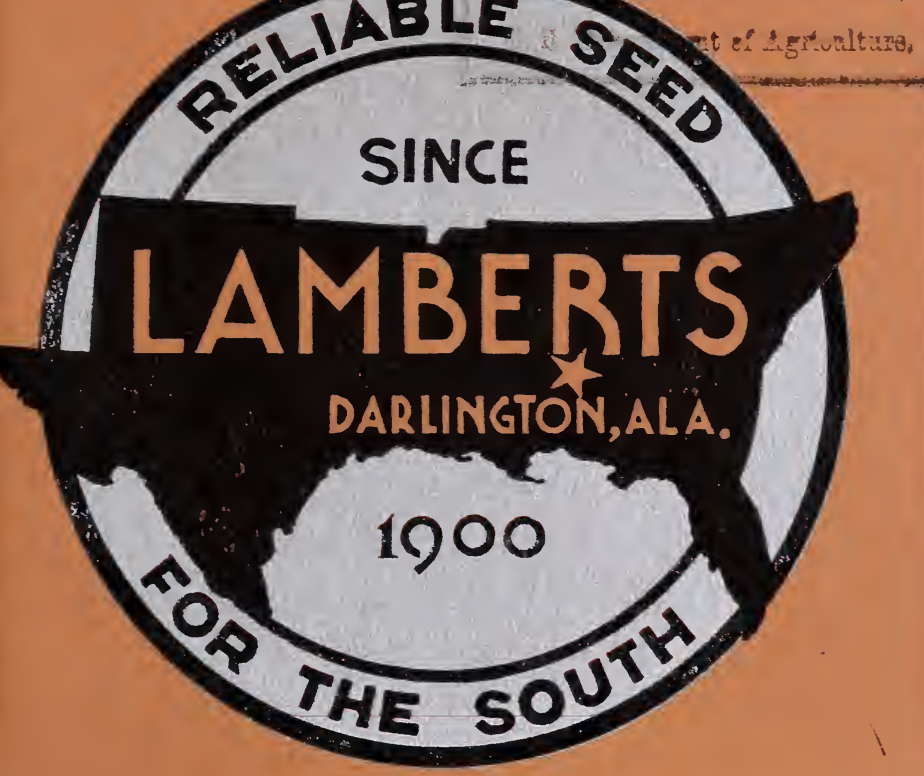

R. E. LAMBERT \& SONS GROWERS-MERCHANTS-IMPORTERS DARLINGTON $\star$ ALABAMA

\section{WHAT TO PLANT? \\ 1937}




\section{N D E X}

- and Weights Per Bushel

Page

WHAT TO PLANT

GENERAL INFORMATION

\section{GRASS SEED}

Bermuda Grass, bu. 40 lbs.

Carpet Grass, bu. 24 lbs.

Dallis Grass, bu. 20 lbs.

Italian Rye Grass, bu. 30 lbs...........

Johnson Grass, bu 25 lbs.

Kentucky Blue Grass, bu. $21 \mathrm{lbs}$

Orchard Grass, bu. 14 lbs. .........

Red Top, or Herds Grass, bu. 40 lbs.

Sudan Grass, bu. 40 lbs..........

Wolf Tail Grass, hulled, bu. 56 lbs..........

\section{CLOVER SEED}

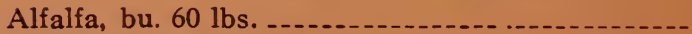

Alsike Clover, bu. $60 \mathrm{lbs}$

Black Medic, bu. 60 lbs.........

Bur Clover, California, hulled, bu. $60 \mathrm{lbs}$.

Bur Clover, Sou. and Early Sou. bu. 10 lbs......-

Crimson Clover, bu. 60 lbs. ..........

Hop Clover, bu. 60 lbs.....................

Lespedeza, Common, Kobe and Tenn. 76, bu. 25lbs.

Lespedeza, Korean, bu. 45 lbs.

Lespedeza, Sericea, hulled bu. $60 \mathrm{lbs} . \ldots$

Melilotus, Annual Yellow, scarified, bu. $60 \mathrm{lbs} . . .-$

Melilotus, Biennial White, scarified, bu. $60 \mathrm{lbs} . . .-$

Persian Clover, bu. 60 lbs. -........................

Red Clover, bu. 60 lbs...........................

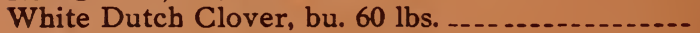

\section{MISCELLANEOUS SEED}

Austrian Winter Peas, bu. 60 lbs...................

Barley, bu. 48 lbs..............

Benne, bu. 50 lbs.........

Cane Seed, bu. 50 lbs......

Chufas, bu. 44 lbs.

Corn, Indian Chief and Whatley, bu. $56 \mathrm{lbs}$

Cotton, D. \& P. L. No. 11, bu. 32 lbs............

Crotalaria, bu. 60 lbs. -...

Millet Seed, bu. 50 lbs. .....

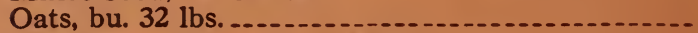

Rape, Dwarf Essex, bu. 60 lbs.

Rice, Upland, bu. 44 lbs................

Rye, Abruzzi, bu. 56 lbs.

Sagrain, bu. 50 lbs.

Sesbania, bu. 60 lbs.

Soy Beans, bu. 60 lbs............

Velvet Beans, bu. 60 lbs. .......................

Vetch, Hairy, bu. 60 lbs.

Vetch, Hungarian, bu. $60 \mathrm{lbs} . \ldots$

Wheat, bu. 60 lbs.

\section{OTHER PRODUCTS}

Beeware and Honey -......................... 43

Cattle, Polled Hereford ......... 42

Inoculation, Nitragin...... 38

Seed Sowers .............. 35 


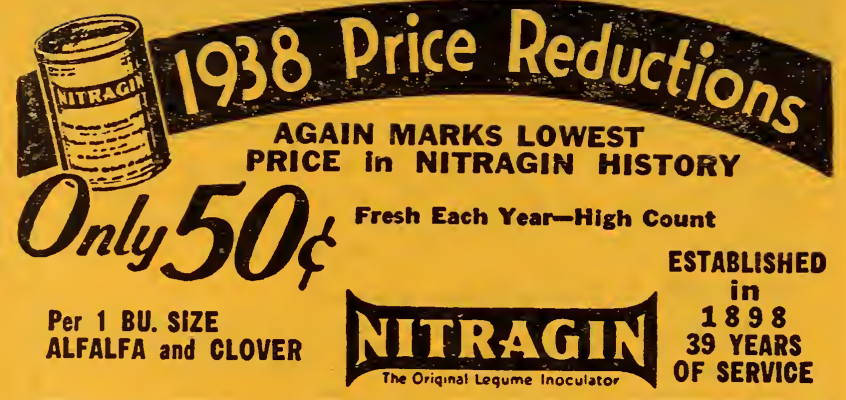

Approved Moist Soil culture - Tested and Guaranteed Easy to Apply - One bu. size inoculates 60 lbs. seed, except Lespedeza - Study culture groups on Other Side.

\section{NITRAGIN INOCULATOR PRICES}

When Ordering, Always State Name of Seed

Culture A \& B

Alfalfa, all Clovers

\section{SIZE}

$1 / 2$ bu.......\$\$ $\mathbf{3 0}$

1 bu......... .50

$21 / 2$ bu......... 1.00

Culture L

Lespedeza

Unhulled or Hulled

$1 \mathrm{bu} . . . \ldots \ldots . \$ .30$

2 bu.......... 50

5 bu........... 1.00

\section{Garden Size Nitragin}

for Peas, Beans, Lupines, Sweet Peas, Lima Beans

Each package will inoculate any amount up to 4 lbs. of seed.

Price 10c each
Culture $S \& E$

Peanuts, Soy Beans, Cow Peas, Lima Beans SIZE PRICE

1 bu.........\$. 30

2 bu.......... .50

5 bu......... 1.00

10 bu......... 1.60

25 bu. . . . . . . 3.00

The 25 bu. size packed only for Soy Beans, Cow Peas and Peanuts.

\section{Culture C \& D}

Vetch, Austrian Peas, Canadian Peas, Beans

$1 / 2$ bu........\$ .25 1 bu......... .40 $12 / 3 \mathrm{bu} .(100 \mathrm{lb}$. size). $\quad .60$ 5 bu......... 1.70 $121 / 2$ bu........ 4.00 The "100 lb." and $121 / 2$ bu. size packed only for Vetch and Pea culture. Bean culture packed only in $1 / 2,1$ and 5 bu. sires 


\section{See OTHE SIDE \\ for 1938 NITRAGIN \\ Price List}

\section{NITRAGIN INOCULATOR CULTURE GROUPS}

Because legume bacteria belong to various groups that work together, it is IMPORTANT, when ordering NITRAGIN inoculation, ALWAYS to specify the kind of seed you wish to inoculate. The list below will help you.

\section{CULTURE A (Rhizobium melloti)}

ALFALFA, SWEET CLOVER (white, yellow), BUR CLOVER (California, Southern, spotted, toothed) bitter clover, snail clover, button clover, fenugreek, yellow trefoil, black medic, Hubam clover.

\section{CULTURE B (Rhizobium trifolii)}

All members of the trifolii CLOVER, including: red, mammoth red, alsike, white, crimson, berseem, buffalo, ladino rabbit-foot, hop clover, low hop and smaller hop clover.

\section{CULTURE I (Rhizobium sp)}

A special culture, related to culture " $\mathrm{E}$ ", but isolated as a particularly effective strain for all varieties of LESPEDEZA, including: Japan clover (common lespedeza), korean, kobe, sericea and Tennessee 76 lespedeza.

Unhulled Lespedeza weighs 25-30 lbs. per bu. seed and requires only 1 bu. size NITRAGIN. Hulled Lespedeza weighs $60 \mathrm{lbs}$. per bu. seed and requires 2 bu. size NITRAGIN.

\section{CUITURE S (Rhizobium japonicum)}

All varieties of Soy Beans

\section{CULTURE I (Rhizobium sp)}

Peanuts, cow peas, black-eyed peas, lima beans, velvet bean, crotalaria, kudzu, Florida beggarweed, mung bean, partridge pea, pigeon pea, tepary bean, tick trefoil, jack bean.

\section{CULTURE C (Rhizobium leguminosarum)}

PEAS: Garden pea, Austrian Winter pea, Canada field pea, sweet pea, tangier pea, flat pea, grass pea, ochrus, broad bean (horse bean), lentil. VETCHES: common, Carolina, hairy, Hungarian, narrow-leaf, wild, spring, Oregon, purple; flat-podded vetchling.

\section{CULTURE D (Rhizobium phaseoli)}

BEANS-Garden (string, snap, wax), kidney, navy and scarlot runner bean.

Special, individual cultures necessary for, Sesbania, Crown vetch, Black Locust, Dalea or Wood's clover, Garbanzo or chick pea, and Guar.

Mandactured by Tho MITRAeIK rOMPAMY, IHG., Milwateo, Whs.

\section{R. E. LAMBERT \& SONS}

P. O., Darlington, Ala. - Express, Camden, Ala. 


\section{CThe}
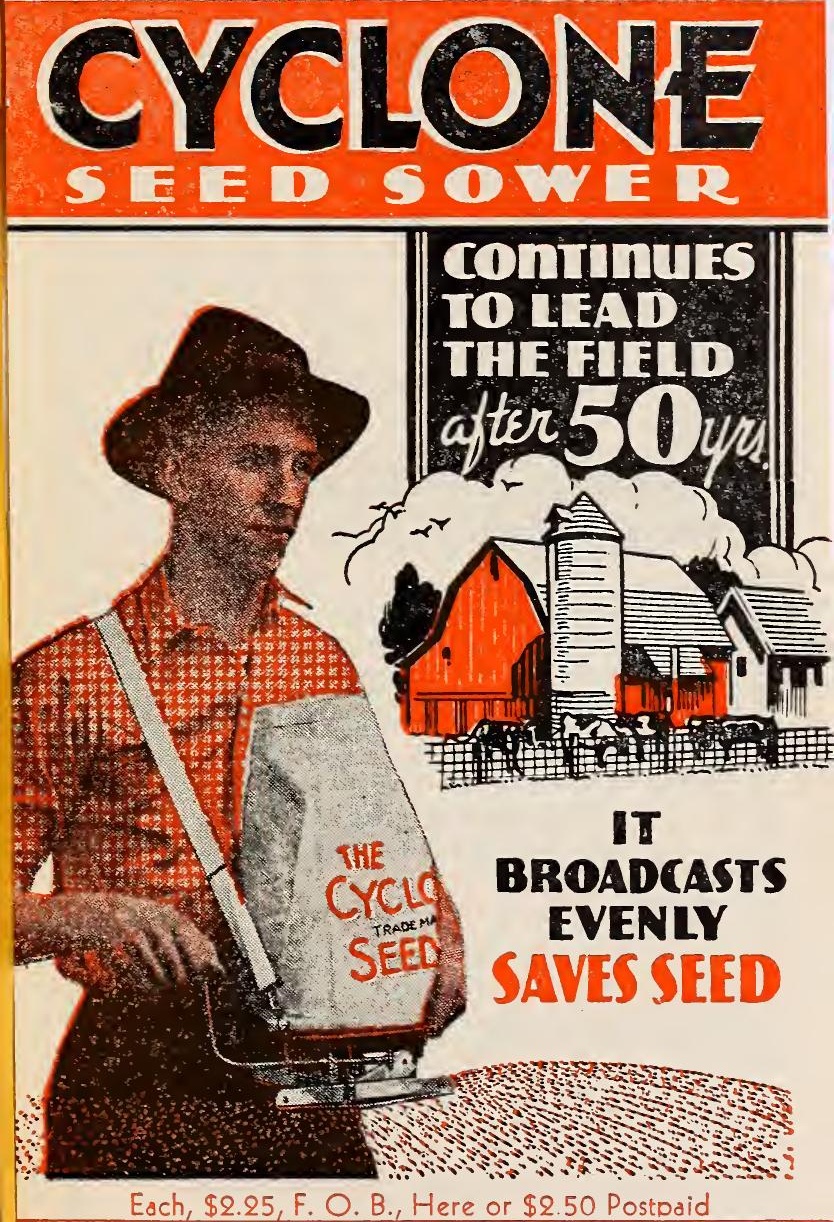

R. E. LAMBERT \& SONS

Farmer-Seedsmen Since 1900 DARLINGTON, - ALABAMA 


\section{The Cyclong Seed Sower}

Broadcasts Evenly - Saves Seed

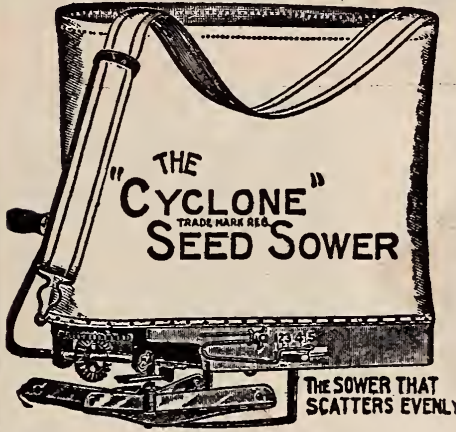

Uneven seeding is wasteful. The "Cyclone" will sow many acres per hour, any amount per acre. Does the works quickly and

SAVES LABOR Many hundred thousands of farmers in America, Canada, Europe and other countries have relied on it for sowing clover, timothy, alfalfa lespedeza, sudan grass, oats, wheat or any other seed that is sown broadcast.

Construction... Its well known double feed insures 2 uniform flow of seed. Sloped Feed Board keeps hopper properly filled. Feed Adjustment is automatic and starts or stops flow of seed instantly. Distributing Wheel scatters seed evenly. Throws equal amounts to equal distances on each side of operator.

The Sectional Tube Style Has Patented Brass Seed Gauge

\section{The "HORN" SEED SOWER}

The tube is made in four sections or joints $\ldots$ They assemble like a stove pipe and not like a telescope.

Will sow perfectly all smooth seeds like alfalfa, clover, timothy, lespedeza, etc., any desired amount per acre and you can rely on this perfect seed gauge. Easily operated-Guaranteed

- For Prices See Reverse Side • 


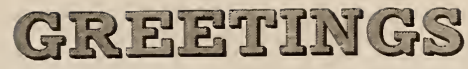

It is a pleasure to present you with this copy of our 1937 catalog, and we hope you will read it with pleasure and profit. It is the result of painstaking effort based on knowledge gained from years of actual farming experience. We have likewise endeavored to give you the benefit of the latest experiment station findings. Therefore, information which is practical and reliable is what we trust you will find contained herein. If you wish any further details, you are invited to write.

With the catalog, we are sending one of our latest price lists. Others are issued monthly, and we urge that you ask for current ones whenever you are in the market for Pasture, Cover Crop, Hay, Lawn, or other farm seed in our line. While, we feel that you will find our quotations attractive, we really solicit your business on the basis of QUALITY and SERVICE first, and PRICE second. We try hard to supply our customers with as high quality seed as the market affords of the respective kinds.

We continue to grow quite a few of the seed we sell, but it would be impossible to produce them all here. We purchase stocks from the leading growing sections of the South and nation, as well as from Hungary, England, Australia, and other foreign lands. Many seed are not in condition to go to you when they are received by us. We see that everything we send out is thoroughly recleaned-and scarified, if this is best. Our recleaning and scarifying equipment is second to none in the South. In a further effort to afford satisfaction, we sack our seed in strong, uniform bags. Many of these have our name imprinted on them, manifesting further that we have confidence in the seed we sell.

Some of the states have seed laws, while others do not. Regardless of this, though, all the bags containing five pounds or more which we send out, have our analysis tags attached. These analyses are for your protection, and ours. We get these tests from federal, state and other recognized laboratories. "Buy by test, and not by guess."

In closing these remarks, giving some insight into how we are prepared and endeavor to serve you, we wish to express deep and sincere appreciation to everyone who has favored us in any way during the year which recently came to an end. During 1937, we earnestly desire to be further favored with confidence and business from our old customers scattered from coast to coast, and at the same time we strongly hope that many new buyers will decide to use Lambert's "Reliable, Recleaned, Tested" seed. We are here to serve, so please call upon us often.

Wishing you much success, we are

Respectfully yours,

R. E. LAMBERT \& SONS,

R. E. Lambert, Jr., Mgr., Seed Dept.

January, 1937

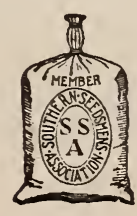




\section{A BIG NEW DAY HAS DAWNED FOR SOUTHERN FARMERS}

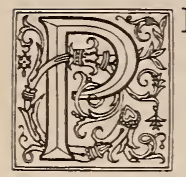

ROBABLY no other section of the globe has a better combination of good climate, abundant rainfall, timber, mineral and power resources, and water transportation from practically every state to the markets of the world than the South.

There is no better cash crop known than cotton, if it is used properly and not abused. A satisfactory civilization, however, cannot be built upon cotton alone. Soils must be cared for, and a living produced, first.

Many farmers make the mistake of trying harder to produce a good cotton crop than plenty of corn. It is true that cotton will help to pay debts, but corn will help to stay out of debt. Years ago the writer heard an observant man say that he had seen farmers "sold out" when cotton was 25 cents a pound, but none with a crib full of corn.

As a result of the clean cultivation of cotton and our heavy annual rainfall of around fifty inches, fertility has leached out, and soils have washed until now many millions of acres are not profitable to cultivate. Practical steps must be taken to remedy the abuse of several decades.

Terracing is necessary on all rolling lands to hold the fertility that is left and make it possible to add more by the use of legumes and phosphate. This is the best help of which every farmer can easily avail himself and use profitably whether on a 20 -acre or 2000 -acre farm.

Lands that are badly washed should be put back into trees. Thus, while nature is curing the abuses of man, a valuable crop can be coming along for future use. It is really surprising how fast some trees grow here in our Southland. Sufficient black locust (a legume) and cedar trees should be grown for fence posts by all farmers.

Recently in our county (Wilcox), the pine timber on one of our largest cotton and cattle farms was sold on a stumpage basis. This timber had been left to grow on the wet and waste lands 30 to 60 years, and should bring in more than $\$ 100,000$. All the timber 20 
inches in diameter and under was reserved for further growth, which was a wise provision. Our foresters are very helpful along these lines, and we should use them more.

It is true that the South has millions and millions of acres of very poor land; and it is equally true that these same lands, where there is a foundation to build upon, can be made productive again through winter or summer legumes and phosphate, and yet a crop of corn, cotton, small grains, or truck be produced every year.

Dale County, Alabama, has been producing hogs on peanuts for over twenty years, and selling them at public sales. The past year the sales averaged almost $\$ 1,000$ a day!

In most sections of the South, soybeans are a better crop for hogs than peanuts. A row of corn and a row of beans is a fine plan. With either soy beans or peanuts, though, the soils are improved. Where the peanuts or beans and hay are harvested and nothing left or put back, the soils are made poorer.

The Southern farmer who lends his best efforts to improving his soils and producing his food and feed is on the road to success, if he manages well, whether on a small or a large farm.

Many thousands of farmers in every state should produce more and better beef cattle, hogs, dairy products, early lambs, and poultry for home consumption and market. A fine help in making the animals more profitable would be to feed the calves, lambs, and pigs some grain in a creep (which can be made with poles) while they run on pasture with their mothers.

Some tender, green grazing will make faster and cheaper gains in hogs along with grain, than where grain alone is fed. A neighbor secured weekly gains of 15 pounds each where fattening hogs had access to a field of Austrian Winter Peas.

Practically every farmer should have some land in permanent grasses and clovers for grazing and hay. Such grasses as Dallis, Carpet, Bermuda, Johnson, and in the middle South, Blue grass, are used most often. To any or all of these should be added some Lespedeza, and then one or more winter growing, reseeding clovers should be grown, such as Hop, White Dutch, Red, Bur, Black Medic, Annual Yellow Melilotus, and in some 
instances, Crimson. Lime is helpful, or necessary on some soils for part of the clovers, and phosphate is so beneficial to all that it is a real "eye-opener."

Every farmer who has never tried phosphate on a winter legume should by all means immediately try some, even if on only a few square yards. To watch the results and observe the improvement over legumes having no phosphate should change a farmer's attitude and plan of farming.

Where, for instance, 200 pounds of superphosphate is applied per acre to winter clovers on sweet soils annually, or 400 pounds of basic slag on sour soils, fine results will continue for years without any cultivation, rebreaking, or resowings. We follow such a plan on a large acreage.

All Southern experiment stations have done excellent work with both winter and summer legumes. Naturally, though, the writer is most familiar with the work done in Alabama.

At Auburn, where soils are very poor, cotton and corn have followed a crop of Austrian Winter Peas or Vetch on the same plots for eleven years, and have been compared with other plots with the same mineral fertilizers, but with no legume. The increased annual yield of corn has averaged $261 / 2$ bushels per acre, and the increased yields of cotton have averaged 1001 pounds of seed cotton per acre for the eleven year period.

Practically all Southern farmers have been growing cowpeas and velvet beans for years, and appreciate their value. There are two rank growing summer legumes that have not been used so extensively, yet, that have great promise. These are Crotalaria and Sesbania, and they are making a large place for themselves in enriching lands for corn and winter truck crops in particular. The Crotalaria grows four to eight feet tall, and the Sesbania six to eleven feet, and they reseed themselves if not sown too late. Phosphate is needed for best results with both, except on fertile lands. It has been shown by Alabama experiments that Crotalaria will easily increase corn yields from 300 to 500 per cent, and will reseed from year to year. Probably no other legume will prove more helpful in giving the South an abun- 
dance of corn. When we have a plenty of corn, we can have bread, meats, dairy products, and poultry, which mean a good living.

Sesbania can also be used in a large way for enriching the lands for corn, and it is particularly fine for winter truck crops. It is often turned under green, and it rots quickly, since it has a hollow stem. We have had a report of a yield of 500 bushels of Irish potatoes per acre in Texas where Sesbania was turned under.

Another thing that both of these plants should prove very helpful in doing, especially the Crotalaria, is in shading out in a large way Bermuda, Nut and similar troublesome grasses.

With so many helpful legumes available, no farmer, in a few years, should be satisfied to farm poor land. In fact, it should be a disgrace to continue to do so.

This suggests a solution of the evils of the tenant system. We can and should first easily make a good living on every farm, and this can be made good enough for anyone. Next, we should produce some other cash crops besides cotton. Then we can still grow plenty of good cotton for the world's markets. 


\section{DESCRIPTION OF PLANTS}

(Read "Planting Instructions" on Page 37)

\section{GRASSES}

Bermuda Grass-This is a hardy perennial grass which grows from frost to frost and is dormant in winter. It succeeds on nearly all soils except constantly wet ones of the South, even if poor and sandy. Its chief use is for pastures, but Bermuda is also a splendid grass for summer lawns and golf courses. It grows well in combination with Dallis and other pasture plants. It is recommended as the foundation grass for upland sandy soils, but in such cases Lespedeza and one of the Bur clovers, White Dutch or Hop clovers, should be sown with it. The clover will give grazing, but, equally important, it will build up the land, and a greater growth of Bermuda will be had. Every 3-4 years it is advisable to apply basic slag or phosphate to the clovers. This plan deserves serious consideration, and a trial. Bermuda's strong root system helps prevent washing. Bermuda is usually sown in the spring, and plenty of moisture helps much in securing stands. For pastures, broadcast 8-12 pounds of good unhulled seed per acre. On lawns, sow at least 1 pound per 225 square feet, and cover very lightly. A third less seed can be used if they are hulled. Moreover, hulled seed usually germinate in about 10 days, while the unhulled require 20 or more.

Carpet Grass-One of the most popular pasture grasses in the lower South and Carolinas. It is not a good hay plant. It is permanent, and gives grazing about nine months of the year. Carpet withstands close grazing, and does not tramp out easily. It spreads rapidly. When well sodded, it crowds out weeds, but also some worthwhile plants. Carpet grass does not fatten stock as well as Dallis and a few others, but it merits an important place because it thrives on some types of land where other grasses do poorly. Most soils will grow carpet, though low moist and cold sandy types suit it best. Seed are sown mainly in early spring, but may be sown successfully any month except in mid-summer. Carpet is not hard to start, but first quality seed should be used. A lot of carpet seed are low grade. Because this 
grass forms such a "carpet," it is being used on many aviation fields and golf courses. Sow 10-14 pounds per acre.

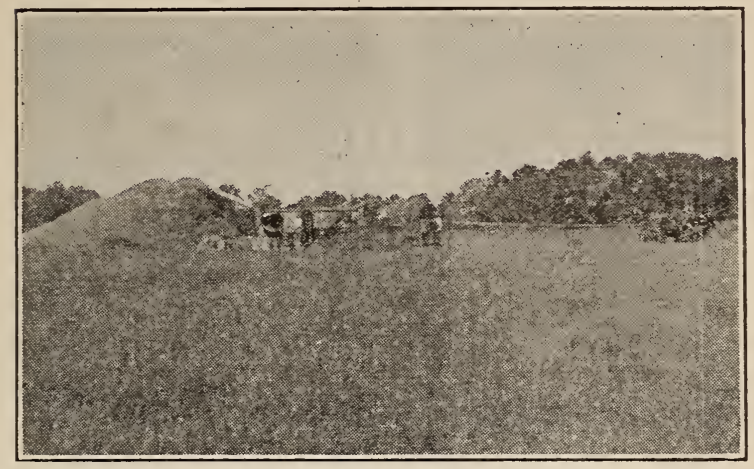

Threshing Dallis Grass seed on the 2300 -acre Lambert farm. This is one of the principal seed crops grown.

Dallis Grass, or Paspalum DilatatumThis plant may be rightfully acclaimed "the king of Southern pasture grasses," because it comes nearer growing the year-round than any other grass whether in mild winter or dry summer, stock prefer it, it fattens better, it stops washed places more quickly, and when well sodded it will give more high class grazing than any other grass we know. Unlike its close relative, carpet grass, Dallis allows its great companions-Black Medic, Hop, Bur, and White Dutch clovers, Lespedeza and Bermuda-to grow freely with it, and when well sodded and closely grazed it largely chokes out objectionable weeds.

Dallis is a permanent grass, and when once started, the job of planting is over. Its roots give succeeding crops whether seed are allowed to mature or not. It is not a pest. Cultivation readily kills it. After getting well established, Dallis is a rapid grower except in cold weather. With a few mild days in winter, its roots immediately send up new blades. This grass makes its fastest growth on moist soils, but gives satisfactory results on dry hill land also. Heavy soils are better for it than the lighter types, but it grows on all and is being established over practically the whole South. Besides being a superior pasture grass, Dallis is a fairly good hay plant. Its dark green color commends it to the eye, and makes it pretty for golf courses and certain lawn purposes. We are the pioneer growers of these seed in the South, but we also import some seed. 
The growth of the two is identical, but the imported seed are harvested under more ideal weather conditions which often improve the quality. Imported Dallis seed cost more than the domestic, but usually fewer pounds may be used. The seed we grow are satisfactory, and are widely used.

Plantings are made the year-round, but principally in late summer and early fall and in the spring commencing in January. Dallis comes up when moisture and temperature conditions are favorable. The seed sometimes germinate slowly, and it may be months before much grazing can be had, but the plant is none the less most desirable. Use $10-15$ pounds per acre.

Italian Rye Grass-Is the ideal grass for winter and spring lawns. It is also very practical and popular for pastures. Dairymen and farmers are making considerable use of it to provide winter and early spring grazing. Splendid grazing is secured from mid-winter to June. Many are turning to this grass to help solve the winter pasture problem. Rye grass must be sown each fall on lawns, but it reseeds on pastures if not grazed too closely at seed maturity time in the late spring. However, seed are inexpensive, and germinate readily with ample moisture. Italian rye grass withstands winters almost perfectly, is deep green colored, and gives highly satisfactory results on lawns. Broadcast the seed on unprepared land, and lightly harrow in, if convenient. Make sure a sod does not withhold the seed from the soil. On lawns, the preparation of the ground is the same whether there is a good Bermuda stand (which is the best hot weather lawn grass) on it or bare places beneath heavy shade. On mellow soils no preparation is needed-simply sow the seed and rake in. On compact soils it is best to loosen the ground with a rake or harrow, then sow the seed broadcast, and cover, or let the rain do it. A light covering of rich soil or fine lot manure will pay. Keeping the ground damp insures better germination. Italian rye grass must be kept mowed on lawns in the spring to avoid shading the Bermuda too much. Late fall and early winter are the best times to plant. Sow 30 pounds per acre on pastures, and 125 pounds per acre on lawns, or 1 pound to 175 square feet. 
Johnson Grass-This is primarily a hay plant, and as such is a splendid one. On fertile land, it usually gives a heavy tonnage of three cuttings of good quality hay, and should be cut when the heads appear. It is a perennial and does best on the heavier soils of the South. Plenty of moisture stimulates growth, but very wet soils are unsuited. Johnson grass is a pest on cultivated lands, but putting the lands in pasture largely eradicates it. Turning and exposing it to freezing weather kills it, also. Sow 20-25 pounds in the spring or summer, and harrow in. Plenty of seed pay.

Kentucky Blue Grass-Is used on pastures and lawns. It will grow on a variety of soils, but fertile heavy soils which contain lime and phosphate, or which can be limed, satisfy it best.

This famous grass has its widest use in the upper South and regions further north. However, it is grown some in the lower South, and the use is increasing. Notwithstanding that Blue grass remains almost dormant in summer, it is our best grass for shady lawns. Bermuda is preferable in the summer where direct sun hits. While Blue grass likes shade, lime is vital to success. Pasture experiments in central Alabama have demonstrated that the protection of shade this far down is not essential to success provided phosphate is applied. Customers are urged to get some Blue grass started. We sell the very best grade of seed. Sow in the fall or early spring at the rate of 1 pound per 200 square feet on lawns, and 10-14 pounds per acre on pastures.

Orchard Grass-Is principally grown in the higher altitudes of the South, but not necessarily so. We have seen it do well in the lower South. It is splendid for grazing and fair for hay. Fall and spring sowings are made, but fall ones allow a longer grazing period. Orchard grass is well adapted for winter growth. It deserves wider use in programs for winter and early spring grazing. It thrives in the shade. Most soils suit this grass, and its heavy sod helps prevent washing. Sow 10-15 pounds.

Red Top, or Herds Grass-In some sections this is the leading grass, and like Dallis grass, it allows other worthwhile plants to 
grow well with it. Red top is especially adapted to marshy places and wet soils having an impervious subsoil. It makes a good growth on dry lands also. This grass has a place in many permanent pastures, as it comes early and continues its sturdy growth until late fall. Like the above grasses, Red Top stands close cropping, and tramping does not injure it. If used for hay it should be cut when it blooms. Sow 8-12 pounds per acre.

Sudan Grass-In general it is a cross between Johnson grass and sorghum, with many of the good characteristics of both and few of the objectionable ones. Sudan grass is used mainly as a hay crop, but is also grazed and used for silage. A field of this grass is very valuable to furnish temporary grazing during the summer, when the pastures run short. Under normal conditions, the growth is rapid. It is an annual, and is not a pest. Two to three heavy cuttings of hay are gotten a season, the feeding value of which is high, being equal to Timothy. Sudan grass is not exacting as to land, but well drained rich loams satisfy it best. It makes more and finer hay when sown broadcast, and harrowed in, but may be sown in rows. Sow in rows, if wanted for silage. Plant from April to August. Sow 20-25 pounds broadcast, or 5-6 in rows.

Wolf Tail Grass-As far as we know, we are the only source of this "evergreen" grass. We offered the seed first in the fall of 1935. The demand has since exceeded the supply. Wolf Tail possesses some rather unusual characteristics in that it remains green and growing the year-around, will thrive in the sun and shade, and succeeds in both heavy and light soils. Strange to say, stock is not so fond of this grass when other green pasturage is abundant, but eat it readily through the winter and early spring. We have known of cattle being wintered on it alone at the rate of two acres for each animal. The stand never gets so thick as to drive other desirable plants out. However, our experience to date prompts us to recommend that the principal plantings be where there is considerable shade, such as in scattering timber and on cut-over lands. Being a perennial deep-rooted sod or bunch grass, similar in this respect to Dallis, it is valu- 
able in preventing soil erosion and catching up washes which have already started. Surely this plant is worth a trial. Plant 12-15 pounds per acre in the fall or spring.

\section{CLOVERS}

Alfalfa-An aristocrat among plants for it must have a fertile, well drained soil with some lime, phosphate and good inoculation. Soils best suited to its requirements are the friable ones of the lime belt, and the fertile clay loams of other sections. When the above conditions are met, alfalfa is undoubtedly the best legume we have for permanent meadows. Five years is an average period of life for a stand of alfalfa from one seeding. It will produce as high as 3-6 tons per acre of the best hay known

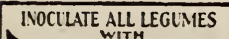
in three to five cuttings. Alfalfa makes a very succulent and nutritious grazing plant for hogs, and one acre will carry 1,000 pounds. It remains green the entire year, but is dormant in winter. When soils and conditions permit, every farm should have a field of alfalfa for the splendid grazing it provides, and for the highly nitrogenous hay it yields. Two of the very best varieties for the upper two-thirds of the South are Kansas and Oklahoma, while Hairy Peruvian is fine for Texas, Louisiana, and the southern parts of other Gulf states. It is popular in short rotations. Kansas alfalfa has consistently produced a heavy tonnage and given long life. Oklahoma runs it a close second. Sow 15-20 pounds per acre broadcast or in drills in September and October, or March and April, on a prepared seed-bed after it has settled well. Then cover not exceeding onehalf inch. Inoculate with Nitragin "A."

Alsike Clover-A splendid reseeding clover that is not so particular about lime as some clovers are. It is especially adapted to moist or wet soils. Alsike is also good for shady places. It is valuable for pasture or hay, and is commonly sown in combination with Red Top and other plants. When so used, it greatly increases the yield. This clover is very resistant to cold weather. As with all clovers, better results are obtained by sowing after the first season in Septem- 
ber, though plantings up to March are possible. If sown alone, sow 3-6 pounds. Inoculate with Nitragin "B."

Black Medic-A wonderful clover that is hardy enough to be grown at least as far north as the Ohio River and northern Oklahoma. No greater blessing could befall the pastures of the South than for Black Medic to be on every acre. INOCLLAJE ALL LEGLMES It spreads as fast or faster TITRECTI than any clover of our acquaintance, and the only soils it will not thrive on, provided they are sweet, are the loose sandy and water-soaked types. Some stable manure is a great aid to getting it started. Phosphate applied in winter will cause it to at least double its growth and thus pay well, and by making the clover better, fertility is added to the soil to increase the growth of the grasses. Liberal mineral applications as above referred to do not have to be repeated each year. Black Medic may be sown from early September to March, the earlier the better. It yields an excellent quality of hay, and it has no equal for permanent pastures for late winter and spring grazing, dying down by July, and reseeding with the closest grazing. It can also be used to excellent advantage for cover crop purposes on cultivated lands, orchards, and meadows, maturing seed in May. This clover is now in much favor for lawns due to its spreading habit, growth in cold weather, and its deep green color. Sow 10-15 pounds on pastures. We usually offer both unhulled and hulled seed. The hulled cost more per pound, but there are more of them in a pound. Also, they can be cleaned better and they come up quicker. Inoculate with Nitragin "A."

Bur Clover-We have three kinds-the old-fashioned Southern (spotted-leaf), Early Southern, and California, and each has its advantages. All usually make vigorous growths and are used for pasture and cover crop purposes. The word "giant" is sometimes applied to the Early Southern, and because it makes a large growth 2 to 4 weeks earlier in the spring than almost any other cover crop, which allows for planting the next crop sooner, it is gaining considerable popularity. 
While the seed cost runs some higher the first time than on most other legumes, one good seed crop will furnish seed for stands for 3 to 5 years with the land continuing in cultivation. Only those seed will come up which are worked to the surface. Another plan is to allow a few seed to ripen each spring before turning. Early Southern is also fine on pastures, but Southern and California are favorites. Both kinds of the Southern are very winter-hardy, and the seed are regularly sold in the bur. We specialize in extra well cleaned seed weighing about 10 pounds per measured bushel. Many seed weigh 12-15 pounds because of the presence of dirt and rocks. Some say this dirt is needed for inoculation, which is not a fact. There are always enough soil particles in the burs to inoculate. California seed are usually always hulled. It costs less per acre to sow the California, stands the first year are easier to get, it grows off faster, withstands dry weather better, and stock prefer this kind. The Bur clovers are adapted to nearly all soils of the Southclays and loams in particular. They work exceedingly well in combination with Bermuda grass. These clovers reseed well late in May, even with close grazing. Fall plantings allow time for more growth, and this is highly important for cover crop use, but many seed are sown in early spring, also, Use 30-50 pounds of seed per acre of the Southern varieties, and 12-15 pounds of California. Inoculate hulled seed with Nitragin " $A$ ", but no inoculation is needed for seed in the bur.

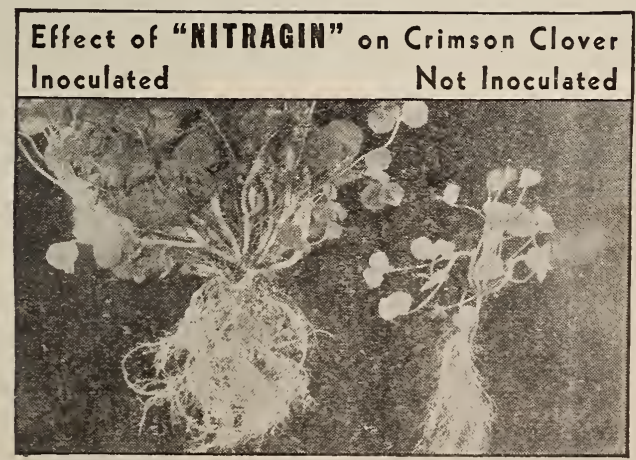

Crimson Clover-Is a clover especially adapted to cultivated lands, and is quite pop- 
ular, even though it must be sown annually. Seed are planted from early to late fall, and are harrowed in lightly when there is a season in the ground. Crimson makes a heavy tonnage and if cut for hay, should be cut while in bloom. However, it is more often pastured some in winter and turned under in spring. Loamy and sandy soils suit Crimson best. Its greatest popularity is in Tennessee and adjacent territory. There is some art in succeeding with Crimson, and inexperienced growers usually come out better with unhulled seed. Sow 20-30 pounds of them or 15-20 pounds of hulled seed. Inoculate with Nitragin "B."

Hep Clover, or Yellow Hop-This permanent pasture clover is a volunteer over a large part of the Cotton Belt. Hop seems to do equally well on Coastal Plain and Piedmont soils. The seed are difficult to harvest, and therefore expensive. However, a few will go a long way because they are very small. Hop is a very valuable pasture clover for late winter and spring. It is one of the

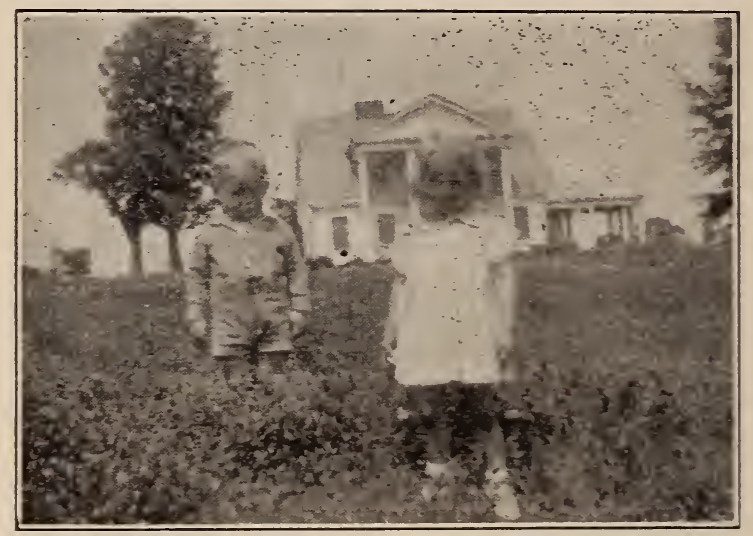

The third generation of Lamberts learning the seed business! This scene vividly illustrates the great value of phosphate on legumes. Both children are standing in Hop Clover. One plot had no phosphate; while the other did, and the growth was 4 times better.

earliest to give grazing, and is splendid in combination with Dallis, Bermuda, Lespedeza, et cetera. Hop responds well in increased growth to an application of $2-400$ pounds phosphate per acre, as do all winter legumes. Be sure to try this splendid clover. It succeeds as far north as the Ohio River, Missouri, and northern Oklahoma. 
Clays and loams that are not constantly wet satisfy it best. Sow seed as early as convenient between early September and March. Use 3-6 pounds per acre. Inoculate with Nitragin "B."

Lespedeza, or Japan Clover-Under this heading we discuss the well known annual varieties, which are Common, Kobe, Korean, and Tenn. 76. Tenn. 76 is improved Common Lespedeza, and is primarily a hay variety, due to its upright habit of growth. Because the plant is quite persevering, Common or Native Lespedeza is yet the most widely grown variety. However, Kobe and Korean make considerably more grazing and hay, and withstand drouths better, than the Common. Korean matures fully 30 days earlier than the others, and it is while Lespedeza is maturing seed that it fattens best. Therefore, Korean provides some high quality grazing that would otherwise be missed. It is especially popular in the northern twothirds of the South, and in the Corn Belt. Kobe makes the greatest growth of the four varieties, and thrives over the entire South. It is popular for hay. In an adjoining county, farmers and stockmen are often able to get one cutting of Kobe hay off of pastures where cattle are grazing and two per year off of meadows, though this is a little unusual. A combination of Common, Kobe, and Korean is ordinarily better than a single variety, and is strongly recommended to provide summer and fall grazing. When the amount of lime in the land increases, the size of Lespedeza decreases. Since acid lands are so common, it is very fortunate that here is a splendid legume which really prefers them. Incidentally Korean is affected less by lime than the other varieties. Lespedeza -referring mainly to the Common, but including all varieties-is grown more extensively than any other Southern legume. This is because it always reseeds, scatters well of its own accord on pastures and uncultivated lands, grows on most soils-including poor acid types, and requires no lime or preparation of the land. The value of lespedeza as a hay plant is increasingly appreciated, and it is often sown among small grains to good advantage. It will yield a cutting of choice hay in the fall, if on moist land. January through March is the usual planting 
season. On pastures sow 12-16 pounds of seed per acre, and 20-25 pounds for hay. Inoculate with Nitragin "L."

Lespedeza Sericea-Is a perennial (comes from the roots more than two years). This rather new legume is remarkable for its success on poor and acid soils. Some have called it "poor land alfalfa." It is an upright grower. The ability of this plant to improve soils where other crops might fail, and to produce heavy yields of hay, has been established. Unquestionably these are the chief uses of Sericea. However, seed production and temporary grazing are further uses. We do not recommend this kind of Lespedeza for permanent pastures. Because the first season is devoted mainly to developing a deep root system, it may or may not be possible to get hay or grazing until later. Stems come from a "crown" or root. After the first year, many more stems come out, giving additional hay and seed. Two-year-old stands, or older, give one cutting of hay and a seed crop, or three cuttings of hay, usually. Since Sericea doesn't reach its best for a season or two, care should be taken to not start it on fields where it will be disturbed too soon. It withstands drouths unusually well. There are two strains. No. 04730 is 15 days earlier, and grows larger, than No. 12087, which is the finer-stemmed and more leafy of the two. Very little attention is now paid, though, to strain numbers. Hulled and scarified seed give best results. Plant about corn planting time, and later, on a prepared and pulverized seed-bed. If seed are what you want, plant 2 pounds of scarified seed per acre. Have rows 3 feet wide, and hills one foot apart, using 15 to 20 seed to the hill. For hay purposes, 12 to 16 pounds of scarified seed should be broadcast.

Cover lightly. Keep down weeds the first year. Harvest seed in late October or early November when fully 75 per cent are brown. Cut the stalks with a knife or mower. Use a flail for small lots, and a thresher for large quantities. We strongly advise scarified seed, and to further assure success, we urge inoculating them with $\mathrm{Ni}$ tragin " $L$ " inoculation. We have it. 
Melilotus, Biennial, or White Sweet Clover - Is one of the best forage plants for lime or limed lands. It requires little drainage or preparation of the land, and is a splendid forerunner for alfalfa which it resembles in looks when small, and gives hay practically as good the first year. It is a biennial which comes from the seed one year and from a deep root system the next. It will reseed if allowed to. It may be planted on pastures or in small grain in the very early spring without preparation of the land. Here in the South two cuttings of hay are had the first year, and one cutting and a seed crop, the second, or grazing entirely, if preferable. Of course, it may be grazed both years and, if so, will furnish an enormous amount of nonbloat feed relished by all livestock, and the second year the roots put out early. As a pasturage plant, white melilotus is not permanent because stock do not let it reseed, but it may be sown every two years and used most successfully along with other plants. No better bee plant is known than white melilotus, and hence may have arisen its common name, "sweet clover." This legume is sown in the fall and spring. Unhulled seed are best for fall sowings, and hulled or scarified seed are best for spring plantings. Sow 14-18 pounds of the former, and 12-15 of the hulled seed. Inoculate with Nitragin "A."

Melilotus, Annual Yellow, or Melilotus Indica-Is one of the best winter cover crops for cultivated lands of the lower South. It is upright, and grows 1 to 4 feet tall, and will produce 5 to 10 tons of green matter by early May which may be easily turned under. Yellow melilotus produces fine quality hay and, if cut when seed start maturing, the land will be reseeded. It is a good temporary grazing plant that stock are foolish about when a taste is cultivated. This plant grows wherever fall sown oats withstand cold successfully, and it is often sown and cut with oats. It thrives best on soils with some lime, and will do well on acid soils if they are limed, which is inexpensive. Where lands are fresh and fertile, or have stable manure applied to aid inoculation in doing its work, results are practically assured. Phosphate is a great aid to this clover, and to all others. If a good yellow melilotus seed crop is turned under, the land may be 
reseeded three or four years from these seed. Only those come up which are worked near the surface in cultivation. This is a popular cover crop for orchards and groves. Disease does not affect it. Stands are easy to obtain on unprepared land. Sow 12-18 pounds, preferably in the fall, though early spring sowings are made. Inoculate with Nitragin "A."

Persian Clover-A relatively new clover that is well adapted for pasture and hay purposes in the lower South, especially where the land is wet,--similarly as Alsike is well suited to regions further north. The growth of Persian is not restricted to damp lands, though. It has a deep enough root system to provide sufficient moisture where moisture is not abundant. On good soils, the growth is usually very heavy; in fact, so much so that some splendid hay can be cut. Persian works well is combination with other clovers and grasses. Plantings should be made in the fall to allow time for the most growth, but many sow in early spring. The seed are larger than such clovers as Hop and White Dutch, of which it is a relative. Sow 6-8 pounds, and inoculate with Nitragin "B." Do not fail to try Persian.

Red Clover-Is a clover which deserves wider use. It is better known in the upper South than in the lower, but we have demonstrated on our south central Alabama farm that it will thrive in the lower regions. We recommend red clover chiefly as a winter and spring pasture clover and soil improver on meadows. Some use it for hay. If used for hay, Red Clover yields one to two cuttings. If fall sown, it makes a large growth, and makes it early. We have known of Red Clover getting large enough to furnish fall grazing which is unusual for winter and spring clovers. It is a biennial. Most soils, except strongly acid types, suit Red Clover. Sow 10-14 pounds in the fall or early spring. Inoculate with Nitragin "B."

White (Dutch) Clover-Is one of the best known and leading clovers for permanent pastures and lawns, but should be given still more prominence and wider use. It accommodates itself to nearly all soils of this country, from the Gulf regions 
northward, and is very hardy. White Dutch is especially useful on sandy and other acid soils, and in this respect holds an advantage over Black Medic to which it is similar. It likes lime lands, also, though. Sow in the fall or spring, the earlier, the better. Under favorable conditions this clover does not die down in early summer, but remains green until fall. While White Dutch thrives in the bottoms and on the uplands, even where there is some shade, it is partial to moist lowlands. When the land is good, and moisture adequate, the growth is usually rapid and abundant. We have been able to carry two or more cattle per acre in the spring on a bottom pasture in which White Dutch and Dallis grass predominated.

It is not easy to tramp out, and at the same time, it restricts soil washing and adds fertility. Some of this excellent pasture and lawn clover should be grown by all. The seed are hard to gather, and naturally higher than some, but are so small that few are required per acre. Sow 3-6 pounds. Inoculate with Nitragin "B."

\section{MISCELLANEOUS SEED}

\section{Austrian Winter Peas and Hairy Vetch for Soil Improvement}

Alabama and Mississippi farmers are in the lead in using winter cover crops-particularly Austrian Peas and Hairy Vetchbut other Southern farmers are fast awaking to the great value of growing them. Because millions of pounds of these seed are sown in the South each fall is proof that great importance should be attached to a proper understanding of just what these legumes will do for a farmer, and to what he should do to be surest of success. To this end we are going to give some valuable space in this catalog to reprint the "SUMMARY" from Circular 74, issued August, 1936, by the Alabama Experiment Station, Auburn, in order that our customers may have the benefit of some of the best and latest experimental tests available. We quote, with permission, as follows:

"The results of field tests to determine the value of vetch or Austrian winter peas for increasing cotton and corn yields and suggestions for success with these crops are given and discussed. These results may be 
briefly summarized as follows:

1. Where cotton and corn were grown on respective areas each year, vetch or Austrian winter peas (turned under) increased the yield of seed cotton by 628 pounds and of corn by 15.6 bushels per acre.

2. The increase in cotton yield due to the vetch or Austrian winter peas was worth $\$ 3.78$ per acre more than the increase from 225 pounds of nitrate of soda or its equivalent after considering the cost of the legume seed and the cost of the soda.

3. Where corn was grown without rotation and was preceded by vetch or Austrian winter peas, the cost of the increased yield was 16 cents per bushel.

4. Vetch or Austrian winter peas grown in a two-year rotation (cotton - winter legume - corn) increased the corn yield 18 bushels per acre at a cost of 14 cents per bushel. In addition to the influence of the legumes on the corn crop, the residue the second year from these legumes increased the cotton yield by 213 pounds of seed cotton per acre.

5. Vetch or Austrian winter peas, when not fertilized with a sufficient amount of phosphate, usually failed to make enough growth to economically increase cotton and corn yields; whereas, with a sufficient application of phosphate they made enough growth to greatly increase the yields of subsequent crops.

6. In order to furnish sufficient Nitrogen for the succeeding crop, it is necessary to turn under the tops of vetch or Austrian winter peas since approximately 90 per cent of the total nitrogen in the legume plant is in the tops at the proper time for turning.

7. The essentials for success with vetch and Austrian winter peas for soil improvement are:

(a) Early planting-September or first half of October.

(b) Planting as close as practical to the old cotton or corn stalks.

(c) Inoculation-if planting on a given area for the first time.

(d) Use 300 to 400 pounds of superphosphate or 600 pounds of basic slag per acre unless the land has been well fertilized with phosphate for several years.

(e) Turning under in the spring when 
the green tops harvested from 100 square feet weigh 15 to 20 pounds.

(f) Waiting at least two weeks before planting the succeeding crop."

It strikes us forcibly that if farmers are really farming for profit they certainly will not put off another year planting Austrian Peas and Vetch after studying conclusions 1 through 4 given above. Besides the more profitable yields following winter cover crops, crops grow off faster and save on cultivation expenses. Why invest in nitrate of soda when winter legumes will gather nitrogen from the air at less cost? Moreover, the winter cover crops perform very important jobs commercial nitrates cannot do. They prevent most of the erosion from winter rains. They add much needed humus to the soil. Crops withstand drouths or wet spells much better when there is plenty of organic matter in the ground. Austrian peas and vetch will give some winter and spring grazing, if it is wanted. Grow your nitrates, and buy only phosphate, potash, and lime!

Austrian Winter Peas-A leading and perhaps the most popular, winter cover crop soil builder of today, but is closely rivaled by "reliable" hairy vetch. The Austrian pea is a kindred plant to English peas, but of much sturdier growth, and is very cold-resistant. It grows on most soils, including acid types, makes a vigorous growth, matures two weeks earlier than vetch, and make a good temporary pasture in late winter. Austrian peas should not be grazed until they have made a good root growth. Broadly speaking, the lighter soils are best for peas, and the heavier ones for vetch.

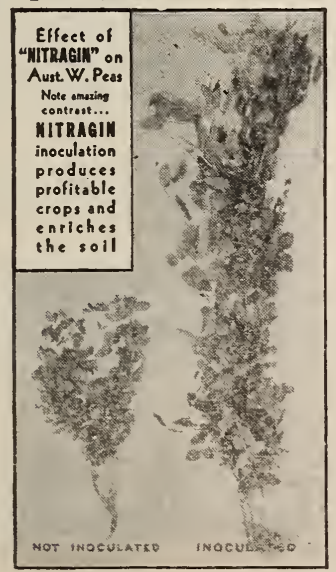
However, both legumes thrive on nearly all soils. Austrian Peas are usually ready to turn by late March. Small grains are fine to plant with them for grazing or hay purposes. Due to large size, $30-35$ pounds of peas should be sown alone per acre, or 20-25 pounds with half the regular seedings of oats, 
rye, etc. Inoculate with Nitragin "C."

Cultural methods for Austrian peas and all retches are the same. Uncultivated lands need preparation, but cultivated lands do not. In either case, cover 1 to 2 inches with sowings from early fall to winter. Early plantings give earlier and greater growth. Late sowings call for more seed than early ones. Increasing the quantities of peas and vetch $20-40 \%$ over what we suggest, will usually make it possible to turn the crops a week or ten days earlier in the spring. A popular method of planting is to broadcast the seed with Cahoon or Cyclone hand seed sowers, and cover with a middle-burster run shallow, a cultivator with small scooters, or a "GeeWhiz" one-row harrow. The middle-burster is especially good on moist or wet lands. Doubtless the surest method of planting peas is with a drill, putting two rows of seed to each crop middle. Seed are easily planted where crops are unharvested, especially when cultivation is clean. It is absolutely necessary to inoculate seed when planted for the first time where peas or vetch have never grown successfully. No other farm crops inoculate for them. The farmer who uses phosphate fertilizers on his cover crops will be well repaid by in creased crop benefits. We vigorously urge that this advice be heeded.

The fertilizer manufacturers now claim that "non-acid forming" phosphate will not injure inoculation, and basic slag will not. Acid phosphate will kill inoculation if exposed directly to it, so if it is used, it should be applied either below or above the seed. Further details about inoculation and fertilizers are under "Information." Also, be sure to read the six "essentials for success" put out by the Alabama Experiment Station under Item 7 above.

Hairy Vetch-Is an outstanding and most reliable soil builder. It frequently costs a little more to use it, but Hairy is a "standby" with many. Poor soils can soon be made rich with it, and practically all soil types grow this variety. It is a favorite on the heavier lands. Hairy and Hungarian Vetches are extremely cold resistant, and are decidedly better than Austrian peas for unfenced lands, where stock have access to the fields when the plants are young. This is at- 
tributed largely to the habit of vetch being late making heavy growth. It may be eaten to the ground in winter, and come out all right by spring. On damp lands, it should be used in preference to Austrian Peas. Vetch is usually turned under in early April, when not left for hay along with small grains, and a good crop is equivalent to 250 pounds, or more, of nitrate of soda. Besides the nitrogen returned, valuable humus is put into the soil. Plant according to directions for Austrian Peas. While September

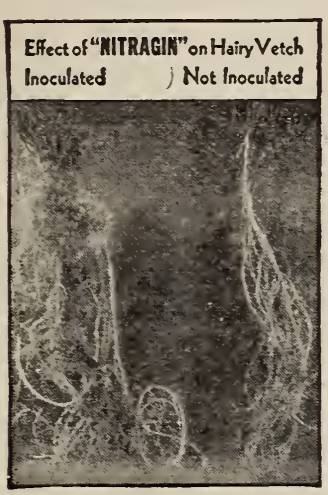
and October plantings a $\mathrm{r}$ e recommended, sowings of vetch as late as December can be made. Vetch seed are smaller than Austrian Peas, and for this reason fewer pounds and less inoculation are needed per acre. Sow 20-25 pounds alone, or 15 pounds with small grains. Inoculate with Nitragin "C."

Hungarian Vetch-Is a favorite with many, particularly in the famous "Delta" of Mississippi, which extends 300 miles from Memphis to Vicksburg, and which embraces a number of counties. The Federal supported Delta Experiment Station, Stoneville, is carrying on extensive experiments with winter cover crops, and we understand that no plant tested by it has surpassed Hungarian vetch. At other experiment stations in Mississippi, Alabama, and other states, Hungarian has likewise given a good account of itself from hardiness and green weight per acre standpoints. This variety is recommended for the alluvial and richer lands, and not for the poorer grades. It costs less per acre to sow Hungarian than Austrian peas or Hairy vetch. Hungarian matures

Fantum some earlier than Hairy, which permits getting the succeeding crop in earlier. It also makes more early growth to give grazing or to turn under than Hairy, although this tonnage may not be apparent to the eye. Sow 25-30 pounds of seed per acre, or 20 pounds 
when planting with small grains. Inoculate with Nitragin "C."

Benne-Is used extensively on game preserves. Quail are very fond of it, and it is probably the very best feed that can be planted in the Southeastern states for doves. It is ideal for this purpose. The seed are formed in a pod, similar to a small pod of okra, and they drop to the ground the entire dove season, with just enough dropping to keep the birds coming. The seed are rich and oily. Other uses of them are for poultry and the manufacture of oil, and by bakeries and confectioneries. Sow in late spring and early summer at the rate of 6-8 pounds in rows or 15-18 pounds broadcast, and cover lightly.

Cane or Sorghum-Should be planted on fertile soils for best results. Texas Seeded Ribbon Cane is the leading member of this family. It grows 10 to 12 feet tall, and makes a good yield of syrup or an abundance of ensilage. This variety is a favorite with dairymen. It is sown in $31 / 2$ foot rows at the rate of 8-10 pounds per acre. There is much confusion as to what is Genuine Texas Seeded, and farmers frequently do not get what they expect. We try to be very careful to secure the real article, and secure the cooperation of experiment stations in this. The earliest sorghum is Early Amber. It is primarily a forage crop, and comes in early. It has helped many a man lay-by a crop when his corn was low. Early Orange is a little later than Early Amber, and produces a larger stalk. Red Top makes a medium sized stalk, a lot of seed, and is fairly early maturing.

Chufas-Are grown mainly in the lower South for fattening hogs. Sandy and loamy soils are preferable. Plantings are usually from April through June in $2 \frac{1}{2}$ to 3 -foot rows, with the hills being about 6-8 inches apart, and the seed being covered 2 inches. Cultivation is similar to peanuts. The crop is ordinarly ready for hogs by mid-September, though later is all right. The hogs do their own harvesting. We sell 44 pounds for a bushel, though some sell only 40 . Use 1 to $11 / 2$ pecks per acre.

Corn, Indian Chief and Whatley-Are very popular prolific varieties, and are among the 
highest yielders tested by Alabama and other state experiment stations. They have medium sized stalks, and average two fullsized ears per stalk. We find Indian Chief slightly earlier maturing than Whatley. The grains of Whatley are white, and the cob is red. Indian Chief is a yellow corn on a white cob. Incidentally, yellow corn has higher feeding value than white. Our seed corn was produced in isolated fields. It is carefully selected and machine cleaned and graded. We consider these operations as being important, but most growers of seed corn are not equipped to give them. We feel confident that our corn will afford entire satisfaction.

Cotton, D. \& P. L. No. 11-Is the leading variety in the central South today. It has been bred up to this leading place by one of the leading plant breeders of the country. The oustanding qualifications of D. \& P. L. No. 11 are: (1) a high percentage of lint40-43\% (1250 pounds of seed cotton will gin a 500-pound bale; (2) it pulls 1 " to $11-16^{\prime \prime}$ staple, which brings a premium of $\$ 4-6.00$ a bale; (3) it is very productive-in fact, it leads all other varieties at many experiment stations; (4) it is early maturing and will set a crop ahead of the boll weevil; (5) it grows a small stalk with scant foliage, which is a splendid qualification under weevil conditions and where the crop is on rich or bottom land; (6) it is storm-resistant, yet it picks easily.

If you plant this cotton you will be more than pleased. D. \& P. L. No. 11 has only been on the market 4 years, so do not confuse it with the older D. \& P. L. varieties, namely No. 4-8 and No. 10.

We buy our entire crop of planting seed direct from the originators every year, and sell only first year seed that are ginned and saved pure. Let us furnish seed for your entire crop at least every other year. The extra premiums will more than pay for the purchase price. You are paying for good seed whether you get them or not.

Crotalaria-Was first introduced into Florida and is now regarded as the South's most valuable summer land builder because it succeeds on almost all soils, including poor sandy types, and because it makes from 15 to 25 tons of green material per acre in normal 
years on poor to average grades of land, which is equivalent to $500-1000$ pounds of nitrate of soda, and because it will usually reseed itself if permitted to do so. It restores fertility easily, quickly, and economically, and is adapted for use by general farmers, tobacco growers, truckers and orchardists on their good and waste lands. One crop puts 3 to 4 times as much nitrogen into the soil as velvet beans do, not to mention the humus which is added if the crop is turned under.

TABLE SHOWING VALUE OF THE DIFFERENT COVER CROPS

(Prepared by the Florida Agricultural Experiment Station)

Dry Wt. Lbs. of Equiv. in Yield in tons Nitrogen Nit. Soda (3-yr. Av.) per Acre per Acre

Crotalaria …..... $2.89 \quad 141.378 \quad 885$ lbs. Cowpeas ........... $1.10 \quad 44.330 \quad 277$ lbs. Velvet Beans... $\quad .85 \quad 37.536 \quad 232$ lbs. $\begin{array}{llll}\text { Beggarweed ... } & .62 & 17.890 & 112 \mathrm{lbs} .\end{array}$

The possibilities of this crop are almost unbelievable. To give only one illustration: if used on all corn lands it would in one year make the South a seller of corn rather than a buyer! A chemical analysis on green Crotalaria above ground, based on only 23,391 pounds per acre, contained nitrogen, phosphoric acid, and potash valued at $\$ 21.91$. Not only is Crotalaria a God-send to the South, but its benefits are spreading to states beyond. There are many varieties, but the most important ones are Late Spectabilis, Early Spectabilis and Intermedia.

Germination is slow due to the very hard coat on the seed, and many will not germinate the first year. In fact, this allows the seed from a crop that is matured to furnish a volunteer crop for several years following. When planting for the first time, be sure to use scarified seed. Scarifying scratches or rubs this hard coat and allows moisture to enter the seed so as to get a uniform germination the first vear. Some scarifiers do their work entirely too vigorously, and often actually impair the germination. We have a large and expensive scarifier which we consider ideal for Crolataria. We do not know of another machine like it in the South. Buy only scarified and recleaned seed from a reliable source. 
Planting. There are several methods that are successful: (1) Drill in 3 foot rows, and cultivate once or twice. A one or two row planter with sorghum plate is the best way to drill. (2) Plant broadcast on well settled, plowed land, and harrow or roll in the seed with a packer. (3) Plant in growing corn on the row, following first hoeing, or broadcast in the middles ahead of the last cultivation, or you may also plant in alternate rows with corn. If the land is very poor, an application of 100-400 pounds of phosphate or basic slag will give splendid results. Early plantings pay best, and should be made after frosts are over, or about cotton planting time. However, plantings can be made from then until the last of July. Cover the seed not over $3 / 4$, to 1 inch. Good moisture is necessary for quick stands.

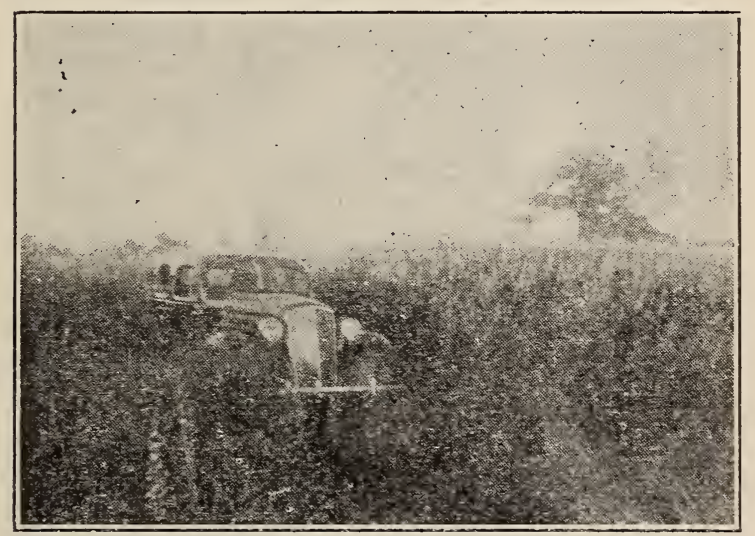

A field of Late Crotalaria Spectabilis planted broadcast. Note the close, dense growth. The height averaged 6 to 7 feet.

Growth. This plant makes slow growth for the first four to six weeks. Therefore, if planted in corn it will not curtail the yield. During July and August rapid growth starts. Broadcast plantings have been found to be very effective in combatting Nut grass, and the U. S. D. A. recommends it for this purpose. It makes such a dense shade that many noxious grasses and weeds are smothered. Seed are produced during October and early November.

Inoculation. Soils on which Cowpeas, Peanuts, and Velvet Beans have been grown inoculate for Crotalaria. However, commercial inoculation is inex- 
pensive, and if you want to be on the safe side, treat the seed with NITRAGIN "E."

Late Crotalaria Spectabilis is by great odds the most widely grown kind since it grows 5 to 8 feet tall and produces the maximum tonnage of organic matter to be turned under. The stalks are pithy and brittle, and are easily plowed under. They decay rapidly. If not turned green, Crotalaria should be turned under in December or January. Spectabilis has no value as a forage plant. Stock usually will not eat it. In fact, it is considered by some to be poisonous, but we have had cattle and sheep to eat it with no ill effects. The seed are black and kidney-shaped. Plant 7-10 pounds in rows, or 16-20 pounds broadcast.

Early Crotalaria Spectabilis is very similar to the Late variety described above, but the growth is usually less. It is recommended for the upper South, and for late plantings at the last cultivation almost anywhere. It matures seed 20 to 30 days earlier than the Late and usually reseeds ahead of frost. The stalks grow from 3 to $51 / 2$ feet tall, yet this is sufficient to furnish a bountiful supply of nitrogen and green matter which is evidenced by the following table:

Average yield 1933-1934

Tennessee

Valley Mountain

Corn after Crotalaria 40 Bus. 44 Bus. Corn after no legume 12 Bus. 6 Bus.

These two sub-stations are located in extreme North Alabama, and these results are certainly significant. Another example of the outstanding value of Early Spectabilis is also had from the Sand Mountain Sub-station, Crossville, where Early Spectabilis was planted and 400 pounds of phosphate applied in 1932. This was done on land producing only 5 to 8 bushels of corn per acre. Since then no seed have been sown or phosphate added. Each Crotalaria crop has reseeded. The average corn yield for the four crops is 40.7 bushels. Could a simpler or cheaper land-building program be wanted? Another application of phosphate now would probably pay. The planting and seeding methods are the same as given under Late Spectabilis above. The seed are identical in looks, so be sure to buy from a reliable source in order 
to know that you are getting the variety that you want.

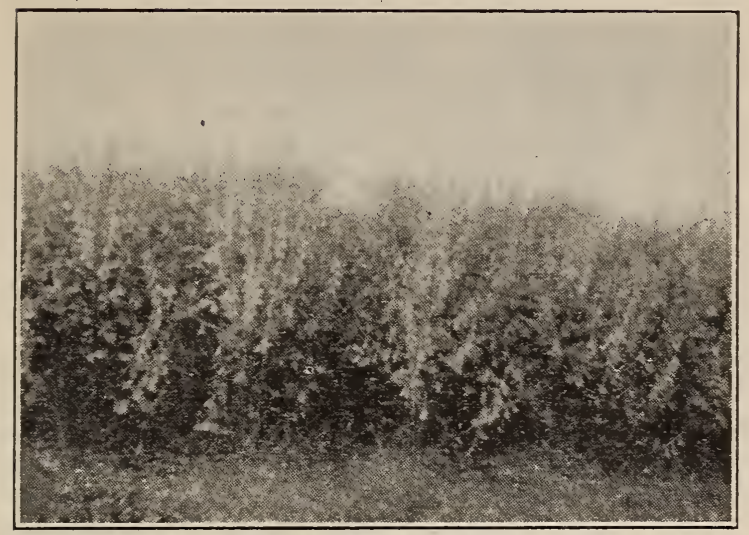

This is a splendid and paying crop of Early Spectabilis. Note it is in rows. The height ran fully feet.

Crotalaria Intermedia-is the only variety which is relished by livestock, and so is a dual-purpose variety. It makes more nodules than any other Crotalaria. The height averages 5 to 7 feet, and if turned under green, the weight runs from 10 to 12 tons. The leaves are long and narrow, the stalk finer than the other kinds, and these features contribute to the value of Intermedia as a hay and silage crop. For hay, it may be cut when two feet high in July, leaving a sixinch stubble. It will resprout and usually give two more cuttings before frost. The seed coat is harder than on Spectabilis, so we scarify twice to insure quick, uniform stands. The seed are golden colored and half the size of Spectabilis; therefore, only half as many are required. Plant 1 to 2 inches deep. For suggestions about inoculation, fertilization, etc., see the information given above.

Millet-A well known variety is Pearl or Cattail. This millet is very valuable to furnish green forage. It will produce through the entire season, giving about four cuttings, if not allowed to go to seed. It comes in fine for dairy cows and other stock. The usual plan is to cut some of it daily, as required. Sow 8-10 pounds per acre in 3-foot rows. German or Tennessee Golden Millet makes an abundance of hay in 6 to 8 weeks. It should be cut for hay when the heads begin to show. Sow broadcast on rich land at the rate of 50 pounds seed per acre. 
Oats, Rye, Barley, and Wheat-Are all fine to sow alone for grain, or with winter legumes to increase grazing and make more and better hay. Oats are also popular to sow alone for hay, and as grain they have a place on most farms for feed or as a cash crop. They can be produced cheaper than corn in many areas, and offer the livestock producer the best solution of his grain problem. The most popular variety from Texas to Alabama is undoubtedly the Texas Red Rust Proof, which Alabama Seed Laws prefer to call Red Rust Resistant. This variety is particularly a favorite in the Black Belt. It is very rust resistant, vigorous, and productive. We try to grow all of this kind we sell. We believe them to be as pure, clean, sound, and heavy as any grown anywhere and sold at any price. We sack them in new printed bags. Coker's 33-50 Smut Resistant is the oat which should be planted by those who have been using Fulghums because treatment against smut can be forgotten, it yields better-usually much better, has a large strong stem, making it storm resistant, and it is early. Because it stools remarkably well, seedings of about 1 bushel per acre are giving excellent results, whereas 2 bushels of other kinds are usually sown. Fulgrain is the latest and most promising variety developed by the famous Coker farms in South Carolina, and the name correctly suggests a heavy yielder of heavy grain. Fulgrain is extra early (5 days ahead of Fulghum and 14 ahead of Appler), is highly smut resistant, is quite cold resistant, shows $13 \%$ higher feeding value than the average southern oat, stools well, and has good stiff straw.

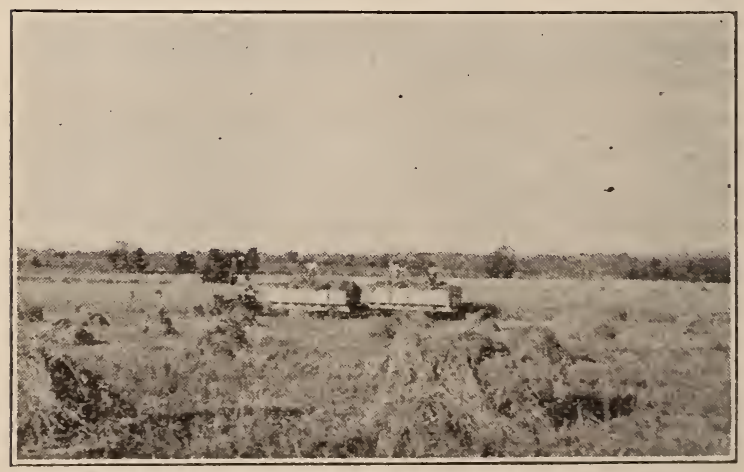

A bumper crop of Texas Red Rust Resistant seed oats being harvested on our seed farm. Modern machinery is utilized throughout. 
Of the small grains, rye ranks next to oats in importance for the South, and Abruzzi is by great odds the most satisfactory kind, because it grows off faster, yields more heavily, stands up well, and produces excellent grazing. Rye is winter-hardy, and will grow on poor lands. Barley is quick growing, and a good feed crop. Sow it only on fertile land. Blue Stem Wheat is a favorite in this part of the country for grazing or for grain. Wheat can stand more cold than any of the small grains. Sowings average 4 pecks of rye or wheat, 5 pecks of barley, and 8 pecks of oats-when sown alone. Use a little over half these amounts with legumes. Applications of phosphate at planting time and nitrate of soda about March 1 usually greatly increase yields of small grains.

Rape, Dwarf Essex-Resembles Rutabaga turnips in leaf and stalk, but is more thrifty and rank. A crop is ready for grazing in 8 to 10 weeks, and is relished as green feed by all stock, but especially hogs and poultry. Rape is popular for "greens" on the table. It is sown from August to May. Fertile soils are required, and seed are sown in drills or broadcast like turnips. Sow 5-10 pounds.

Rice, Upland-Is used for general feeding purposes on the farm. Also, it attracts doves and other birds, but doves especially like it. Flooded lowlands are not necessary for growing this kind. Any fairly fertile land having a reasonable amount of moisture is suitable, and should produce 20 to 40 bushels of 44 pounds each. Plant from late spring to early summer at the rate of 3 pecks per acre in $21 / 2$-foot rows, or $11 / 2$ bushels if broadcast, and cover 1 or 2 inches. Fertilize the same as for corn.

Sagrain-Is a wonderful forage and grain crop which resembles sorghum in looks, but is a rival of corn in the production of grain and for ensilage purposes. It will produce twice as much grain as corn under identical conditions, and considerably more forage. Sagrain will grow on lands unsuited for other grain. It will thrive with excess rains or drouth when corn will not. It will do much to solve our feed problems, and is relished by all livestock and poultry. The grain has 90 per cent of the feeding value of corn, pound for pound. When the 
heads mature, they may be cut with knives and fed to live stock and poultry with or without being threshed. The stalks are relished by stock. They are cut easily with a hoe or "poor man's harvester." Plantings are made from April to August. Nearly all soils suit Sagrain. Drill 4 to 5 seed 9-10 inches apart in rows $3-31 / 2$ feet wide. Stands should be thinned to about 2 stalks per hill for the most grain. Sow 8-10 pounds seed per acre.

Sesbania Macrocarpa, or Indigo PlantHas been a volunteer summer and fall legume in many waste places of the South for years. Now, besides being fine on many "thrown-out" lands, it is a wonderful and popular summer soil builder for farmers and growers of cantaloupes, lettuce, Irish potatoes, citrus fruits, etc., from southern California to South Carolina. Although a warm weather plant, good results have been had as far north as Oklahoma and Kentucky, and points higher up. Being a very rapid and quick grower broadens the field of use. The heavier bottom soils suit Sesbania best, but it will succeed on other types, even though they be quite dry or wet. Some cultivation and fertilization helps on the lighter, upland soils. Most plantings are made broadcast with no other crop being on the land at the time, but another good practice is to sow the seed just ahead of the last plowing of corn, etc. The earlier the "laying-by," the better. Naturally, greater benefits in nitrogen and humus are obtained by turning the crop green, and on good land, this is possible in 8 to 10 weeks after plant-

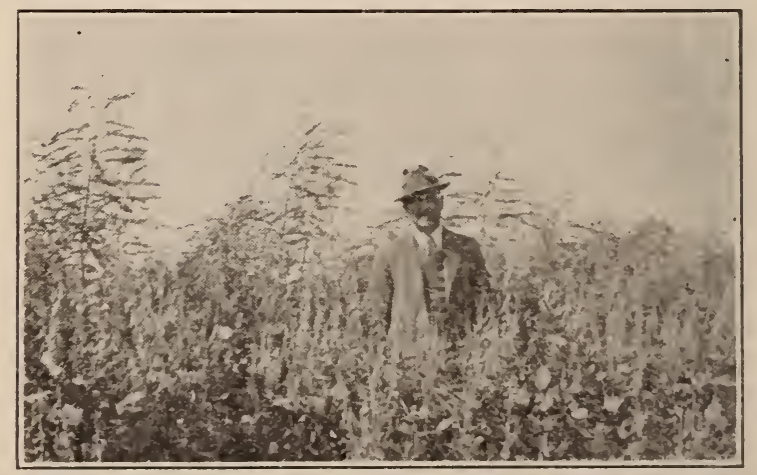

Does this mass of vegetation look like a lack of fertility and humus for the next crop? Crotalaria is in the foreground, while the tall legume in the rear is Sesbania. The picture was made at Versailles, Ky., on Oct. 3, 1936. 
ing when the stalks are usually 6 to 10 feet tall. The stalks decay rapidly. Sesbania is the greatest nitrogen gatherer of which we know. When grown for soil improvement, the nodule development will be surer and greater by inoculating the seed with Nitragin "Sesbania" inoculation. It is offered in 1937 at the same prices as culture for cowpeas and soybeans, which is cheap. "Legumes NOT inoculated are 'SOIL ROBBERS,' and Legumes WELL in o culated are 'SOIL B U I L D ERS'!" Plantings run from April to mid-July. A fair stand can be had from broadcasting $15-20$ pounds per acre, but truckers who want thick stands should sow 30-40 pounds. Cover about one inch, when convenient to cover. Care should be observed, though, to plant scarified seed ONLY. The Sesbania seed coat is very hard, and only $10 \%$ of unscarified seed may germinate the first year. We recommend and sell scarified seed. This plant is not a pest. Cultivation readily kills it.

As a quail feed Sesbania is unexcelled. Where quail are scarce, sportsmen would do well to follow the successful plan of the famous 12,000-acre Maytag Preserve, "Sedgefields," Union Springs, Alabama. Let Mr. Geo. L. Harden, Jr., Manager of this preserve, briefly tell the story, thus: "Through observations made on the Maytag Preserve the most important factor to be considered in making quail abundant is a plentiful supply of feed, not too far removed from sufficient cover. By the process of opening the craw of all birds killed and by experimenting with the planting of different seed it was possible to determine the kind of feed quail like best. After careful consideration over a number of years the conclusion was reached that Sesbania is the most suitable seed to plant. It grows well on most any type soil, produces large quantities of seed and quail will eat it in preference to any other feed. This has been satisfactorily proven." Just enough seed fall from the pods to give feed continuously from late fall to spring. Sow about 25 pounds per acre from April through June, preferably early in the upper South and preferably in long strips 30 feet wide, but also in patches, along edges of fields and ditch banks, and almost any 
waste places. It is desirable to lightly disc or harrow the seed in, but often no covering or other attention at all is given. Sesbania

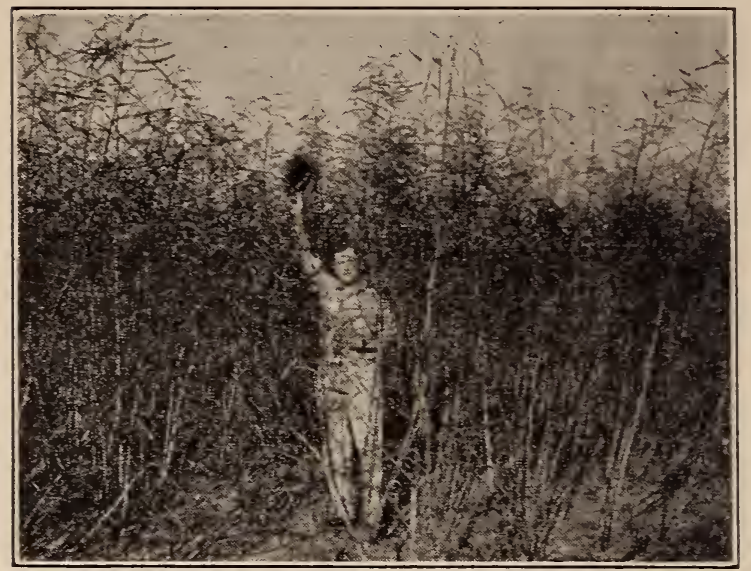

The man in the picture is a real one- 6 feet tall. He is standing in a South Carolina field of Sesbania. The time is late fall, after the leaves have fallen.

is easy to grow. It thrives best on moist, heavy lands. Another use of Sesbania is for duck feed. It succeeds in marshy places, and will actually grow in shallow water around ponds and lakes.

Soy Beans-The most exINOCLLATE ALL LEGUMES NTRed] tensively grown soy bean is the Mammoth Yellow. It is a large and erect grower. It is grown for beans and forage. Mammoth Yellows are fine to "hogdown." The beans are yellow. The Biloxi, which is a brown colored bean, is also fine to turn hogs on in the fall. It is upright in growing, and produces an abundance of foliage and beans. It does not pop badly. The Biloxi is about 25 days later than the Mammoth Yellow. It is well to have a field of each. This is the cheapest way to fatten hogs.

The Laredo soy bean is popular because it is reasonably early, is an abundant bearer, and will produce under favorable conditions Like Laredos, Otootan beans are black. This variety is late, but it makes up for this by giving an abundant growth. It yields a large quantity of fine-textured hay and many sections place their chief dependence on it. The Tokio is a greenish vellow bean, and like the Laredo is a good general purpose variety. The seed are cheaper.

Sow soy beans preferably in drills. It 
pays to inoculate them with Nitragin "S." A peck of Mammoth Yellow, Biloxi and Tokio beans per acre, and a half peck of Laredos and Otootans, are average seedings.

Velvet Beans, Early Epeckled or 90-Day, and Bunch or Bush-The former is a running bean, and the most widely used variety. However, Bunch velvet beans are gaining in popularity, especially for use on rich lands where the running kind makes an excessive vine growth which wraps up the corn badly. Being vineless, this variety can be used advantageously with other crops besides corn, as well as in orchards. It can be utilized for hay and green forage. Some can be cut daily with a hoe. Bunch velvets will make when planted as late as May and early June, but for best results, plant both varieties earlier. Velvet Beans are extensively interplanted with corn. They are wonderful soil builders, and valuable producers of fall and winter feed. The seed of the two varieties are identical in appearance. The usual planting is one peck per acre. If you wish to inoculate, use Nitragin "E."

\section{SEED SOWERS}

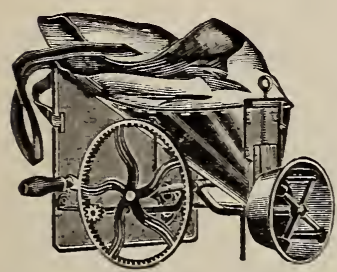

Cahoon Hand Seed Sower-Durable and dependable for sowing Austrian Peas, vetch, oats, lespedeza, grass and clover seed, etc. Perhaps the best hand broadcasting machine made. Has adjustable small and large feed gates for different sized seed. Metal 11x10 in. breast-plate. Gears and frame are malleable iron. Capacity, 22 qts. Shipping weight, $8 \mathrm{lbs}$.

Prices: $\$ 4.40$ f. o. b. here; $\$ 4.75$ postpaid.

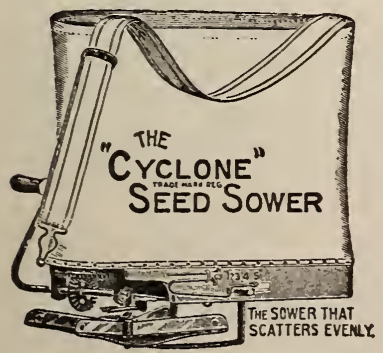

Cyclone Hand Seed Sower-Recommended for sowing all small and large seed which are commonly broadcast. Si m ply constructed, e a s il y operated, and very popular. It is adjustable. Oscillating feed plate wont clog. Capacity half bu. Shipping weight, 4 lbs.

Prices: $\$ 2.25$ f. o. b. here; $\$ 2.50$ postpaid. (35) 


\section{WHAT TO PLANT}

For Winter Corer Crops-Make selections from Austrian winter peas, Hairy and Hungarian Vetches, Early Southern Bur Clover, Annual Yellow Melilotus, Crimson Clover, Southern and California Bur Clovers, rye, oats, barley, wheat, Rape, and to some extent-Black Medic, White Dutch, Hop, Persian, and Alsike Clovers.

For Summer Soil Improvement Purposes-Crotalaria, Sesbania, soybeans, velvet beans, cowpeas, peanuts, and Lespedeza (all kinds).

For Permanent Pastures-Make your choice among Dallis, Bermuda, Carpet, Wolf Tail, Red Top (Herds Grass), Orchard, and Kentucky Blue Grasses; and from such clovers as Black Medic, Lespedeza (Common, Kobe, Korean), White Dutch, Hop, Bur (California and both Southerns), Persian, and Alsike. Italian Rye and Rescue Grasses belong in this group, if not grazed too closely at seed maturing time, so as to permit reseeding.

For Temporary Pastures-Use White Melilotus (Sweet Clover), Yellow Melilotus, Alfalfa, Crimson Clover, Red Clover, Lespedeza Sericea, Italian Rye Grass, Rescue Grass, Johnson Grass, Sudan Grass, Vetch, Austrian Peas, small grains, Rape, and soy beans.

For Hay-Choose among Alfalfa, Yellow Melilotus, White Melilotus, Kobe and Tenn. 76 Lespedezas, Lespedeza Sericea, Crotalaria Intermedia, Black Medic, Red Clover, Crimson Clover, soy beans, cowpeas, and Johnson, Sudan, Red Top, Rescue, Dallis and Orchard Grasses. German Golden Millet is used considerably for hay in some sections. Fine hay is gotten from a combination of Austrian Peas, Vetch, or Yellow Melilotus with oats, rye, barley, or wheat. Add plenty of grain to the mixture.

For Grains and Forage-Corn, oats, rye, barley, wheat, Upland Rice, Sagrain, soy beans, Early Speckled and Bunch Velvet Beans, cowpeas, Cattail Millet, and Texas Seeded, Amber, Orange, and Red Top canes or sorghums.

For Lawns-Buy Italian Rye Grass (the best winter and spring grass), Bermuda Grass (the best summer grass), Kentucky Blue Grass, Canadian Blue Grass, Black Medic, White Dutch Clover, Hop Clover, and for certain purposes (golf courses, aviation fields, etc.), Carpet, Dallis, and Orchard Grasses.

For Feed For Birds-Sesbania, Benne, Upland Rice, cowpeas, soy beans, Lespedeza, Millet and Sagrain. The peas usually furnish feed in the early fall before other crops have ripened. 


\section{GENERAL INFORMATION}

Planting Instructions-Are not considered necessary for small grains, sorghums, millets, corn, cotton, cowpeas, soy beans, and velvet beans. However, we have given planting suggestions and instructions in the foregoing descriptions of Austrian Peas, Vetch, Alfalfa, Crotalaria, Crimson Clover, Rape, Sagrain, Sesbania, Upland Rice, Benne, Chufas, Bermuda Grass, Italian Rye Grass, Johnson Grass, and Sudan Grass. In the case of the other grasses and clovers we sell-which are principally pasture plants -no preparation of the land is essential. However, this does not mean that a drag harrow run over the surface once or twice, preferably after sowing the seed broadcast, will not pay. It should be done whenever convenient, and it is especially desirable where a sod is on the land, or the surface is sloping, and drifting of seed by rains might occur. We have sown pastures and fields many times without doing anything besides scattering the seed by hand or with a Cyclone or Cahoon seeder. It is cheaper, and usually better, not to plow for pastures, but if it is done then the soil should be allowed to settle before the seed are sown-since a firm seed-bed is essential to success. Be sure not to get small grass and clover seed covered over one-half inch at any time. If it is desirable to plant Yellow Melilotus, Lespedeza or some other clover, with small grain, sow the grain in the usual way, and scatter the small seed over the surface.

Pasture seed are usually sown broadcast, but planting in shallow drills (without covering), and putting out in small piles are good methods, also. The latter plan can hardly ever fail if fine barnyard manure is mixed with the seed, and seed requiring inoculation are well inoculated. Seed sown in drills and piles are longer giving maximum grazing than if broadcast, however. Those who sow only one grass or clover, and expect a satisfactory pasture, will usually be disappointed. A combination of at least two grasses and two clovers should be used, even if all are not sown at one time, or in one year. It usually takes 25-35 pounds of seed per acre to give a good start and a variety. 
Do some experimenting every year. Increased plant growth due to liberal seeding will pay many times over whether enriching land or feeding stock. Do not be sparing with seed. Furthermore, it is the exception and not the rule, when a good permanent pasture is established within six months. It should improve each year.

Inoculation-Isn't merely advisable, but is necessary for most legumes unless being planted on land where kindred crops have been recently grown successfully. Even then, money spent on inoculation is good insurance. Poor inoculation, or no inoculation, is responsible for more legume failures than any other cause. Often farmers do not realize the importance of inoculation, and omit it, to their regret and loss. Good inoculation prevents a sickly growth after germination, and insures a better

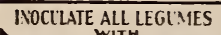
stand and yield. It pays well in producing larger crops. Soy bean yields are often increased 25 to 100 per cent by inoculating the seed. It is an easy operation, and the cost averages only 15-20c per acre. Some double the required amount of inoculation to be on the safe side. Southern Bur Clover carries its inoculation in the burs, but no other clovers do. Lespedeza is usually not inoculated except in western Texas and Oklahoma. Vetch, Austrian Peas, Crotalaria, Sesbania, Black Medic and all other clovers require inoculation, unless the soil contains the proper bacteria. Soy Beans should be inoculated. No grasses, small grains, Rape, cane, millet, corn, cotton, Chufus, Upland Rice, Benne, Sagrain, or Grohoma need inoculation.

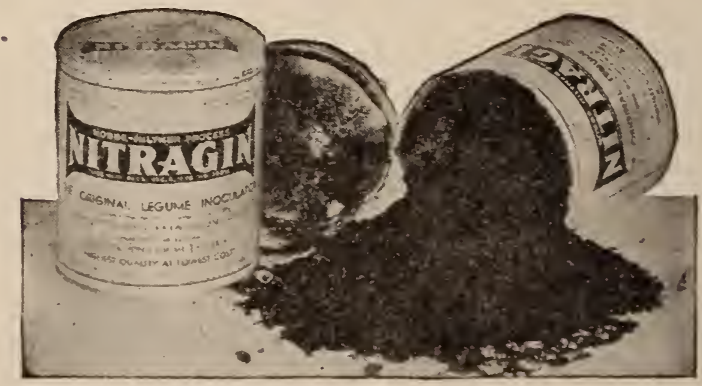

We sell NITRAGIN INOCULATION, "The Original and Dated Inoculator" put up in 
handy tins. The culture groups or "families" are:

"A"-Alfalfa, Black Medic, all Sweet Clovers or Melilotus (including Hubam), and California Bur Clover.

"B"-Alsike, Crimson, Hop, Persian, Red, and White (Dutch) Clovers.

"C" Vetches, Austrian Winter Peas, Garden and Sweet Peas.

"D"-Field and Garden Beans.

"E"-Crotalaria, Peanuts, Cowpeas, Velvet Beans, Beggarweed, and Kudzu.

"L"-Lespedeza (all varieties).

"S"-Soy Beans (all varieties).

"Sesbania"-For Sesbania.

Legumes NOT INOCULATED are "SOIL ROBBERS"-take more plant food out of the soil than corn or any other grain or grass crop.

Legumes WELL INOCULATED are "SOIL BUILDERS"-restore, maintain and build up soil fertility.

When ordering, be sure to specify kind of seed to be inoculated. The various kinds of NITRAGIN are put up in different sized cans, and our price lists quote. Seed may be inoculated with soil, and the usual rate is 1 pound for 5 pounds of seed. Soil on which a legume has recently grown successfully will inoculate for all legumes in that group. Soil inoculation is not greatly used now because the commercial is cheap, easier to use. and much surer of success.

How to Inoculate-Each can of inocula. tion has these simple directions on it: Place seed on floor, on canvas, or in tub. Mix contents of this can thoroughly with water. Large seeds (Soybeans, etc), require about 1 pint of water per bushel of seed. Smal? seeds (Alfalfa, etc.) require about 1 quart of water per bushel of seed. Pour NITRAGIN mixture gradually on seed. Mix well until all seeds are thoroughly coated with the black substance. Seed will dry in a few minutes. PLANT AS SOON AS POSSIBLE. If soil is used, it should be dry and pulverized, and be stirred into dampened seed (not wet). If the soil is sandy, some syrup or glue in the water will cause some soil to stick to every seed, which is the desired objective. 
Fertilizing Materials-Have a tremendous effect on legumes. Results are impressive whether applied on cover crops or pasture clovers. Better clovers mean richer lands; richer lands spell better grasses. First in importance is superphosphate (acid phosphate), second, lime, and third, stable, manure. All soils need $2-400$ pounds phosphate per acre of legumes, or 4-600 pounds basic slag, unless they follow a crop liberally fertilized with phosphate. Four tons increase in green matter is common from such applications. It is best to apply basic slag on lands deficient in lime, and phosphate on the soils containing lime. Basic slag has some lime in it, and may be put out with and when the seed are, but plants should be up when phosphate is applied, unless contact with inoculated seed can be avoided, or unless "Non-acid Forming Phosphate" is used.

Straight acid or superphosphate will kill inoculation.

Most soils are benefited by one to four tons limestone every five years. If put out in much quantity, lime should be added as early as convenient before planting. Every farmer should begin liming part of his farm every year, where needed. Sweet soils pay.

County Agent W. G. Yeager, Rowan County, N. C., has conducted hundreds of tests to prove that all lime loving plants can be grown on acid soils. The plan is simple and inexpensive. The seed are treated with double the usual amount of inoculation, and basic slag is applied liberally. This important discovery has been verified by 20 -odd experiment stations of the country.

Prices-Are subject to change without notice and stocks being unsold. Our latest price list is sent with this catalog, and we issue new ones monthly during main seasons. We are glad to furnish current quotations at any time, but do not attempt to send them voluntarily to our entire mailing list. Being farmer-seedsmen, with many over-head expenses eliminated, we can and do sell below the market usually. However, it is not on the basis of price alone that we solicit your business, but on Quality and Service.

All prices are f. o. b. our shipping points, Estelle and Camden, on the L. \& N. R. R., or point of no higher rate, unless otherwise stated. 
Quantity Prices-We try to give reasonable price concessions on large lots, and invite inquiries. Ask for delivered quotations.

Terms-We can give better prices and service by requesting cash with order. Remittances should be made by money order, check, draft or money by registered letter. Stamps wrapped in wax paper are acceptable for small amounts. Shipments may be made C. O. D. or B/L attached, but we urge customers to send money in advance to save collecting charges. Agricultural colleges and others operating under similar systems are accorded the buying privileges with us, to which they are accustomed.

Non-Warranty-We give no warranty, expressed or implied, as to description, quality, productiveness, or any other matter of seeds or plants we send out, and will not be responsible for the crop. When given, purity and germination figures are for information only and without guarantee. No responsible seedsman gives any warranty because most of the failures are due to unfavorable weather or soil conditions, too deep or too shallow planting, unsatisfactory inoculation, etc., all of which are beyond his control.

How to Wire Us-Our phone number is 1011. Camden, Ala., is our telephone exchange and Western Union office. Selma, Ala., is our Postal Telegraph office. There are no extra charges for phoning wires to use from either place. Customers are respectfully requested not to wire us collect, particularly when asking for quotations. Our prices do not allow for this expense.

References-Camden National Bank, Camden, Ala.; City National Bank of Selma, Selma, Ala.; Dun \& Bradstreet, Inc.; and many agricultural leaders throughout the South.

Transportation to Use, and Rates-Parcel post is cheaper than express for small quantities, and larger amounts often go economically by it. 70 pounds may go in one package-150 miles for 84 cents, 300 miles for $\$ 1.47$, and 600 miles, for $\$ 2.52$. Seed are insured when money is sent for it. Seed take the 2nd class rate by express, and for this reason many customers use this quick service for medium and large orders. Many express agents do not handle seed often, and do not know that the 2 nd class rate applies. Customers are urged to ask their agents 
about the express rate charged. If you are not rushed for seed, freight is the cheapest transportation on 100 pounds or more, and sometimes less. Most seed take 3rd class freight rates. Some seed which are entitled to 4th class (lower) rates include Sudan Grass, Johnson Grass, Sagrain, sorghums, and peanuts. Austrian Peas and cotton seed take 6th class east of the Mississippi, and 4 th if they cross the River. Oats, rye, barley, wheat, cowpeas, velvet beans, and soy beans take 10th class, (the lowest), east of the Mississippi River, and 4th if they cross it. We will gladly furnish any freight, express, and parcel post rates. Delivered prices will be cheerfully furnished at any time. Do not forget to tell us how and where to ship.

NOTICE-If seed are to be sent prepaid, or by parcel post, be sure to allow money for the purpose unless you do not mind the $C$. O. D. fees, as we cannot charge these small amounts. Consult your agent or postmaster for rates, or let us give them.

\section{OTHER PRODUCTS FOR SALE}

Registered Polled Hereford Cattle-We have the largest polled herd in the Southeastern States, averaging 250 head, and well known blood lines are represented. Many cattlemen look upon Polled Herefords as "the preferred beef breed" of today. For 20 years we have bought our herd bulls out of leading herds in the North and West at a cost of $\$ 500$ each. The herd is Government accredited. Breeding stock is for sale at all

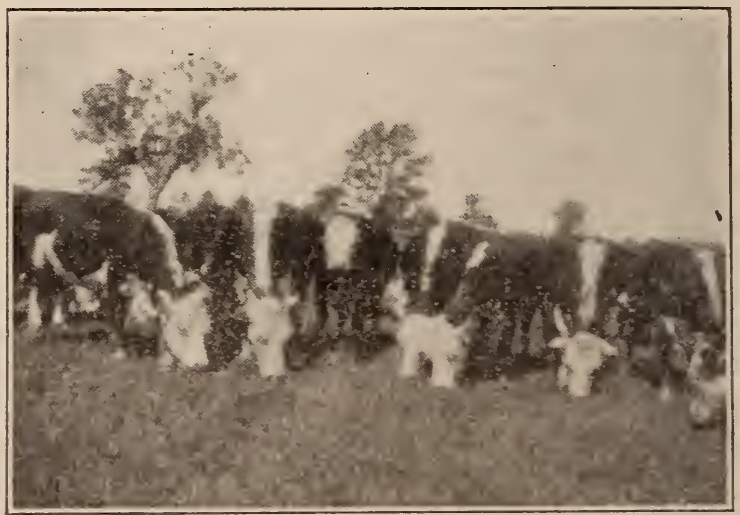

Some of the Lambert registered polled Hereford heifers. The horns are bred off. The "white face" outnumbers all other beef breeds combined. 
times. We have many satisfied mail order customers in seven states. Correspondence solicited. Visitors are welcome.

Pure Honey, extracted, and made bright and delicious principally from white sweet clover is for sale as long as it lasts. Delivered prices subject to market changes are: 5 lb. pail, 85c; $10 \mathrm{lb}$. pail, $\$ 1.50$.

Bee Supplies-Manufactured by G. B. Lewis Co., Watertown, Wisconsin, and $\mathrm{Da}-$ dant's Foundation, are carried in stock. This is a leading line of beeware, and is used by the Alabama Polytechnic Institute. Write us for the Lewis catalog.

What You Want in seed may not be listed, but we will do our best to quote you if same is available. Your inquiries are solicited.

If our literature has interested you, we believe it will interest your friends. PLEASE SEND US THE NAMES OF SOME GOOD FARMERS. We will gladly mail this catalog to them, and your name will not be used if you prefer.

\section{WHAT OTHERS SAY OF US AND OUR SEED}

"To Whom It May Concern:

Camden, Alabama

Jan. 12th, 1937

"We have known and patronized R. E. Lambert \& Sons, farmers and seedsmen, for a number of years and have known the members of the firm intimately. Their products have always proved to be of high grade, and our relations very satisfactory." CAMDEN NATIONAL BANK E. W. Berry, President

Selma, Alabama January 11, 1937

"To Whom It May Concern:

"The firm of R. E. Lambert \& Sons, Darlington, Alabama, in our opinion, has been of great benefit to the farmers and stock raisers of the South. Their reputation for fair dealing and thoroughness in business cannot be questioned.

"We believe that any transactions you might have with them will prove entirely satisfactory. We appreciate them as customers, as well as citizens of this community."

THE CITY NATIONAL BANK OF SELMA By H. Glenn Boyd, President

\section{OTHERS FROM ALABAMA ...}

"By referring to your records, I think you will find that I have been a purchaser of fine clover and pasture grass from you for the past 8 or 10 years. It goes without saying that my relations with your firm have been most satisfactory."

L. W. ASHLEY, Montgomery County 
"As your records will show, I have been a purchaser of your seed for quite a number of years, and have yet to be disappointed in them. The seed purchased have been exactly as represented, in-so-far as I could tell. As a matter of fact, I have been so well pleased that I do not hesitate to send you an open order for any seed I wish to purchase."

A. E. GRUBBS, Farm Manager ALLISON LUMBER CO., Sumter County

"We handled quite a lot of your White Clover and Hop Clover seed last Spring, and in every case were well pleased with quality of seed and stands obtained."

LIMESTONE COUNTY EXCHANGE, INC. C. B. Braly, Manager

"R. E. Lambert \& Sons have proven themselves worthy seedsmen, soil builders, Master Farmers, and friends of farmers and pasture builders of the South." J. N. DENNIS, Chilton County

"The 15,000 pounds of vetch seed that we bought from you in 1936 on guaranteed delivery were received, and we found them to be of high quality and in good condition.

"We may say further that for several years we have had business relations, and in every instance we have found the quality of your seed and the service that you gave us to be above par and very satisfactory. We commend you as being a very capable and dependable source of supply for seeds." J. F. SUTTLE, JR., Perry County

"I have sold Lambert's seed for a number of years, and our customers have obtained the best results. The fact that these seed have been of the highest test has caused the demand for Lambert's seed to increase more and more in our section."

THE FARMERS' EXCHANGE

Mamie P. Searcy, Mgr., Butler County

"It gives me pleasure to advise you that I have, during the past ten years, purchased seed from you for grain, cover, and pasture crops, and have always found your service prompt, your prices right, and the quality of your seed most satisfactory. You have done a constructive work through the development of better farming and better livestock in Alabama. It has, therefore, always been a pleasure to do business with you."

ROBERT JEMISON, JR., Jefferson County

"Your records will reflect our having purchased from you better than $\$ 3600.00$ worth of seed this past summer, consisting of Dallis Grass, Black Medic, Bur Clover, Austrian Peas, and Vetch. The seed were planted according to your directions, and we are glad to report splendid results were obtained.

"We believe your seed very desirable for all lands belonging to us, being approximately 13,000 acres near Geiger, and we will be buying additional seed throughout the years, as we contemplate extensive improvements in our pastures, as well as more legume crops annually for our cultivated fields."

SUMTER FARM \& STOCK COMPANY

O. J. Henley, Gen. Mgr., Tuscaloosa County 
"I have just returned from a vacation in Texas where I saw some of the best pastures I was ever in. The pastures I refer to are located at Teague, Texas, and owned by Bib Riley, and Burt and Riley Middleton. When I was there the 15th of June, Dallis grass was better than knee deep, and they were cutting it for hay as they had a surplus of grass. Common Lespedeza and Carpet Grass were ankle deep. They informed me that they had bought the pasture grass seed from you."

E. E. HALE, County Agent, Baldwin County

"We are pleased to tell you that we have had better results from seeds purchased from you during the past two seasons than from any other source, and have therefore decided to purchase our field seed from you next Spring."

CLARKE COUNTY EXCHANGE, INC. Guy Hamilton, Manager

\section{FROM ARKANSAS ...}

"I have done some experimenting yearly with clover and grass varieties realizing our pasture crops are really the most valuable and the most important crops grown. Lambert's plump, clean seed were sown liberally, and the good stands of sturdy plants received was a pleasure. Lambert \& Sons' valuable booklet "What to Plant" reflects their outstanding knowledge of pasture plants."

C. W. MARTIN, Jackson County

"It is with a great deal of pleasure that I reflect upon our pleasant dealings with your good firm in the past. Every transaction that I have had with your firm has been satisfactory in every respect.

"I have always found your seed to be of the highest quality, really better than represented. Your prices have been reasonable and your service dependable. When I have been asked for a source of supply for such seed as you handle I have unhesitatingly recommended your firm. For where fair treatment, dependable seeds and service are wanted, I know of no better source."

ARTHUR G. LEE, Sebastian County

\section{FROM FLORIDA ...}

"This office handled cooperatively last Fall, 37,500 pounds of Austrian Winter Peas, all of which we purchased from your Concern. All of our plantings from these seed produced a very good stand, and we are very pleased with the percent of germination. Having purchased seed from your Concern, of various kinds, during the eight years I have been County Agent, in Florida, I wish to assure you that my dealings with you during that period have been satisfactory and most pleasant.

J. W. MALONE, County Agent, Jackson County

"Lambert \& Sons have supplied Walton County, Florida, farmers with all kinds of seed for the past several years, which have been satisfactory in every way."

MITCHELL WILKINS, Co. Agt., Walton County.

"It gives me pleasure to state that during the several years of my business dealings with you, I have found your service entirely satisfactory."

R. B. HARKNESS, M. D., Columbia County 
FROM GEORGIA ...

"We have been doing business with you now for many years, and if all the seeds we have bought from you were put together there would be many carloads of them. So far as we recall in all our dealings with you over a long period of years we have never had occasion to make a single complaint either about your seeds or your service.

"We always feel safe when we trade with you because we know you are men of high character, and that we can depend on you to ship us seeds as you represent them, also that you will not fall down on your deliveries, and that you will not violate your contracts or agreements in any way."

SNELSON-WELLS CO., Chatham County

\section{FROM KENTUCKY ...}

"I am well pleased with the Crotalaria that I received from you. It is over four feet high now, and the early kind is already making pods. The big kind is still growing strong, and the Sesbania is doing fine. The drouth here had very little damaging effect on them."

J. STANLEY HUGHES, Woodford County

\section{FROM LOUISIANA ...}

"I was out at Mr. Hutton's place this morning, and we are getting a very nice stand of clovers from our seeding. ..."

W. E. DEE, Agronomist, Webster County

\section{FROM MISSISSIPPI . . .}

"I have been buying your seed over a period of ten years, and have always found them satisfactory in every way. Our business relations have been very pleasant, and I hope to continue them for many years."

W. L. DOUGLASS, Lowndes County

"It is a pleasure for us to be able to recommend the seed that you supply. We feel particularly qualified to do this due to the fact that we have bought seed of different varieties from you at least fifteen years, and have always found your seeds to be of good quality."

\section{E. F. NUNN \& CO., Noxubee County}

"For a number of years we have purchased many varieties of seed from R. E. Lambert \& Sons, and are glad to recommend them as what we believe to be reliable shippers."

\section{THE GADDIS FARMS}

By J. L. Gaddis, Jr., Hinds County

"I have been dealing with R. E. Lambert \& Sons for several years, and find them to be reliable in every respect. The seed they send out is of the best quality."

COLLINS PRODUCE AND SEED COMPANY

By F. L. Crump, Owner, Covington County

"We have used your seed for a number of years and have found them the best, and do not hesitate to recommend your seed to any of our farmer friends."

THE PEOPLES BANK \& TRUST CO.

By V. S. Whitesides, President, Lee County 
"I recommend R. E. Lambert \& Sons as reliable seedsmen for the South. A view of my pecan grove at Ocean Springs, Jackson County, Mississippi, on Highway No. 90, will convince you, as they selected and furnished the seed that produced as nice a winter cover crop and spring and summer pasture as you would want to see. I have been using Lambert's seed for the past five years."

I. F. PRITCHARD, Jackson County

"I would like to take this opportunity of expressing my satisfaction in my dealings with you.

"I have found R. E. Lambert \& Sons very prompt in their shipments, and their seed of the very best quality, and these two qualities we appreciate very much in those from whom we buy our seed."

C. E. RHETT, Manager

T. J. Moss Tie Company, Lowndes County

\section{FROM NORTH CAROLINA . .}

"We are happy to renew our many years of dealing with your firm again in 1937. It has always been a pleasure to transact business with a firm whose integrity we have always held to be so high, and whose stocks we have always found to be of a uniformly high quality and dependability."

JOB P. WYATT \& SONS COMPANY

By W. Greyson Quarles, Mgr., Wake County

\section{FROM OKLAHOMA . .}

"Your best grades of Dallis Grass seed have always come up to samples and expectations, being well cleaned and pure and satisfactory germination."

CLARKE \& KELLER SEED STORE By F. D. Keller, Pottawatomie County

"We have been buying what seed we could from yourselves for several years, and have always found that the quality and grade has been up to our expectation.

"It has been a real pleasure to do business with a firm that we can have full confidence in, and we know that the seed we buy from R. E. Lambert \& Sons will be as good or better than represented to be."

\section{ROACH SEED COMPANY, Okmulgee County}

"I have bought nearly all kinds of seed from you for the past six or seven years, and have found them of the highest type that could be grown. I think you are the best seed house in the South. Your business is built on honor and principle is why you cover such a wonderful territory."

HENRY R. LATIMER, McCurtain County

\section{FROM SOUTH CAROLINA ...}

"We own and operate a dairy farm in the lower part of this state. For a number of years we have been buying Lespedeza, Carpet Grass, Clover and other seed from you, and always we have found your seed pure and high in germination."

J. W. SMOAK HARDWARE COMPANY

By W. C. Bethea, Gen. Mgr., Orangeburg County 
"It is a pleasure for us to write and tell you all of the various seeds we have bought from you from time to time have given our customers perfect satisfaction."

E. W. BAILEY SEED CO., Charleston County

"For the past five years, I have been purchasing, from time to time, various farm field seeds from you, and the fact that I have consistently dealt with your firm, in spite of distance and higher freight rates to pay, in preference to seed establishments nearer at hand, bespeaks quite clearly, I think, the high regard I have for the service you have rendered. When in need of good seed, or information in regard to field crops in general, I think of your place as headquarters for such, and I have yet to be disappointed in any particular."

$$
\text { W. M. SCOTT, Pickens County }
$$

"I have done considerable seed business with the Lamberts. All of these transactions have been pleasant and satisfactory in every way. I especially appreciate the fact that contracts for future delivery of seed have always been fulfilled in detail though prices had advanced considerably after purchase was made. In all of my seed purchases from Lamberts, I have received entire satisfaction in QUALITY, SERVICE, and PRICE."

W. C. WHITE, Chester County

\section{FROM TENNESSEE . . .}

"We are very glad to express ourselves in saying that our business relationships for a number of years with you have been most pleasant and satisfactory, and we look forward to a continuance of same."

R. B. BUCHANAN SEED COMPANY

By Mrs. Katharine Treanor, Vice-Pres., Shelby Co.

"For many years I have felt that it is very fortunate that in the R. E. Lambert Seed Company we have seedsmen who specialize in seeds adapted to the lower South. If it is a southern pasture, forage or soil improving crop, generally the Lambert Seed Company will have the seed for it."

L. R. NEIL, Editor

Southern Agriculturist, Nashville

\section{FROM TEXAS ...}

"Honest Seedsmen-Good Seed."

\section{THE BENNETT RANCH}

Jackson County, Texas

"During each of the last several years I have purchased from you anywhere from the fer pounds of the initial purchase of clover and pasture grass seed to something like 1,600 pounds during 1936 .

"I have always received prompt attention on $\mathrm{my}$ orders, and have found your seed to be just as represented. Your prices plus freight from a considerable distance usually are lower than those of nearer dealers plus less freight."

\section{HOWARD HAMPTON, Red River County}

"I have been purchasing farm seed from you for some ten years and have always found you dependable and satisfactory." J. W. FITZGERALD, Smith County 


\section{VISITORS ALWAYS WELCOME}

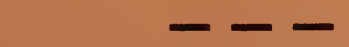

Darlington post office is located on our 2300-acre farm, which lies between and near the intersection of Highways No. 10 and 11. Highway No. 11 passes through the edge of the plantation. Darlington is 10 miles east of Camden, 37 miles west of Greenville, and 40 miles south of Selma. Strangers should inquire for "Lambert's Farm." Signs are on all nearby roads. 


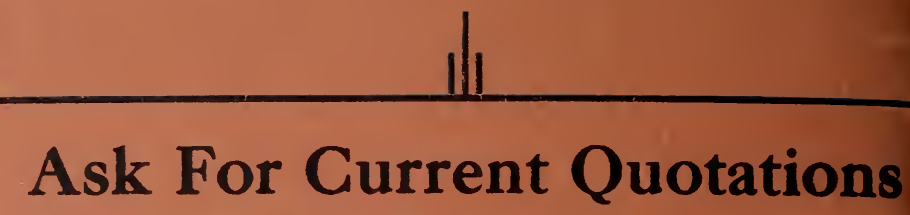

We Issue Price Lists Monthly During Main Seasons
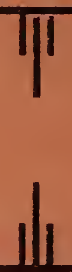

Under “General Information"

\section{Have You Read}

ABOUT FERTILIZING MATERIALS, INOCULATION, AND PLANTING INSTRUCTIONS? ALL OF THESE A R E IMPORTANT SUBJECTS. LOOK THEM UP, AND STUDY THEM CAREFULLY. SEE INDEX ON INSIDE FRONT COVER.
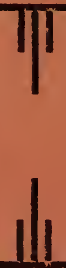

WE SUGGEST THAT YOU KEEP THIS SMALL CATALOG HANDY. YOU MAY WANT TO REFER TO IT MANY TIMES. 